Ensaios para compreensão de uma prática psicológica em construção: Atendimento Online (via e-mail) 


\section{LUCIANA RUFFO}

Ensaios para compreensão de uma prática psicológica em construção: atendimento online (via e-mail)

(versão corrigida)

Dissertação apresentada ao Instituto de Psicologia da Universidade de São Paulo, como parte dos requisitos para obtenção do título de Mestre em Psicologia.

Área de Concentração: Psicologia Escolar e do Desenvolvimento Humano

Orientadora: Prof ${ }^{a}$. Dr ${ }^{\mathrm{a}}$. Henriette T. P. Morato 
2016

AUTORIZO A REPRODUÇÃO E DIVULGAÇÃO TOTAL OU PARCIAL DESTE TRABALHO, POR QUALQUER MEIO CONVENCIONAL OU ELETRÔNICO, PARA FINS DE ESTUDO E PESQUISA, DESDE QUE CITADA A FONTE.

Catalogação na publicação

Biblioteca Dante Moreira Leite

Instituto de Psicologia da Universidade de São Paulo

Ruffo, Luciana.

Ensaio para compreensão de uma prática psicológica em construção: atendimento online (via e-mail) / Luciana Ruffo; orientadora Henriette Tognetti Penha Morato. -- São Paulo, 2016.

$74 \mathrm{f}$.

Dissertação (Mestrado - Programa de Pós-Graduação em Psicologia. Área de Concentração: Psicologia da Aprendizagem, do Desenvolvimento e da Personalidade) - Instituto de Psicologia da Universidade de São Paulo.

1. Atendimento psicológico online 2. Orientação psicológica online 3. Psicologia e Internet 4. Atendimento mediado por computador I. Título.

RC489.I54 
RUFFO, L., Ensaio para compreensão de uma prática psicológica em construção: atendimento online (via e-mail). Dissertação apresentada ao Instituto de Psicologia da Universidade de São Paulo, como parte dos requisitos para obtenção do título de Mestre em Psicologia.

Banca Examinadora

Prof. Dr. Instituição

Julgamento Assinatura

Prof. Dr. Instituição

Julgamento Assinatura

Prof. Dr. Instituição

Julgamento Assinatura

Dissertação Aprovada em: 
À meus pais, Irineu e Adirce por todo apoio.

À meu marido, Ricardo, por toda cumplicidade.

À meu filho, Alexandre, por tanto amor. 


\section{Agradecimentos}

À Adirce e Irineu, meus pais, por todo o apoio em tantas diferentes esferas da minha vida.

À Ricardo, meu marido, por estar sempre a meu lado, me apoiando quase que incondicionalmente.

À Alexandre, meu filho, por me mostrar o quão intenso pode ser o amor e a aceitação de alguém.

À minha grande família, meus irmãos, cunhados e sobrinhas, sempre presentes em todos os momentos.

À Henriette Morato, por toda sua paciência e dedicação. E por me permitir dar forma a esse sonho de muitos anos.

Aos amigos do LEFE, André Nunes, Marcos Gorenstein, Laiz Chofi, Paulo Evangelista, Pedro Milanesi, Vitor Sampaio, Gilberto Barreiro, Walter Cautella por tantas reflexões. Agradeço em especial a Heloisa Aun por sua disponibilidade e companheirismo. E a Géssica Czuy, por tanto apoio e amizade, por ter me ajudado a achar um rumo, mesmo sem saber que rumo é esse.

À Rosa Farah, por ter me aberto tantas possibilidades. Por seu constante incentivo, sempre acreditando em mim.

À Lorival Novo (in Memorian) por me ensinar a olhar as entrelinhas em cada mensagem.

Aos amigos do NPPI deste e de outros tempos, em especial Ana Luiza Mano, Katty Zuniga, Paulo Lopes, Juliana Zacharias, Ivelise Fortim, Erick Itakura, Guilherme Ohl e Andrea Jotta, por descobrirem junto a mim os mistérios do virtual e partilharem de tantas discussões $e$ reflexões virtuais e presenciais.

Aos amigos virtuais do MUD, por tanto me ensinar desse universo. Em especial Mateus "Berseker" Bonesso, pelas noites de xp e papos sem fim trazendo diversão ao meu caos, Duarte "Xaero" Souza Garcia pela atenção, cuidado e respostas as minhas muitas perguntas sobre d3 e a Vitor "Saruman" Cardoso, por me incentivar a sempre continuar em frente e buscar meu sonho.

À CAPES pela bolsa a mim concedida

À Ilca Zanini, por ter me ajudado a lembrar quem sou.

À todos os clientes presenciais e virtuais que fazem o meu dia a dia muito mais completo. 
"O que é real? Como você define o 'real'? Se você está falando sobre o que você pode sentir, o que você pode cheirar, o que você pode saborear e ver, o real são simplesmente sinais elétricos interpretados pelo seu cérebro." (Morpheus - Personagem do filme Matrix) 
RUFFO, L. Ensaio para compreensão de uma prática psicológica em construção: atendimento online (via e-mail). 2016. 74 f. Dissertação de Mestrado - Instituto de Psicologia da Universidade de São Paulo. São Paulo 2016.

\section{Resumo}

O presente trabalho busca apresentar um panorama geral da aproximação da Psicologia com a tecnologia trazendo à tona a questão dos atendimentos psicológicos online, suas limitações e possibilidades. Os atendimentos online são regulamentados pelo Conselho Federal de Psicologia e devem seguir uma serie de normas, sendo possível apenas sua realização como orientação psicológica ou ainda como psicoterapia se em caráter experimental. O foco de atenção nessa dissertação será o atendimento enquanto orientação online, visando uma melhor compreensão sobre qual o seu sentido. Busca-se apresentar, através da análise de alguns emails recebidos pelo Núcleo de Pesquisa de Psicologia em Informática da PUC- SP que vem realizando orientações online através de e-mails desde 1998. Por esse procedimento, encaminham-se questionamentos e reflexões a respeito do fazer psicológico no meio virtual escrito. São também ensaiadas algumas questões na direção de compreender as possibilidades de atuação do psicólogo nesta modalidade de atendimento.

Palavras-chave: Atendimento Psicológico Online; Orientação Psicológica Online; Psicologia e Internet; Atendimento mediado por computador. 
RUFFO, L. Essay for Comprehending a psychological practice to be built: Online Attendance (e-mail). 2016. 74 f. Master Dissertation - Psychology Institute of São Paulo University. São Paulo 2016.

Abstract

The aim of this work is to present an overview of the approach of psychology with technology concerned to online appointments, their limitations and possibilities. Online Counselling are regulated by norms issued by the Federal Council of Psychology (Conselho Federal de Psicologia), and are restricted to the practice of psychological orientation and experimental psychotherapy. This dissertation intends to develop the concept of online attendance on the psychological counselling, in order to provide a better knowledge of its field of application. Research was based on e-mails received by PUC-SP Psychology in Computing Research Center (Núcleo de Pesquisa de Psicologia em Informática da PUC- SP), which has been performing online orientation appointments since 1998, and consists of presenting questions and deliberations about the psychological practice in the online written environment. Specific questions in order to understand the psychologist's practice in this kind of counselling are also discussed.

Key-words: online counselling; online psychological attendance; psychology and internet; computer mediating psychological attendance. 


\section{Sumário}

1. Apresentação

2. Introdução

2.1. Tecnologia e Psicologia

2.2 O Núcleo de Pesquisas da Psicologia em Informática (NPPI)

2.3 Questionamentos para encaminhar uma reflexão

3. Objetivos:

3.1 Geral: $\quad 22$

3.2 Específicos:

4. Metodologia 23

$\begin{array}{ll}\text { 5. Algumas mensagens recebidas } & 27\end{array}$

5.1 A análise dos e-mails recebidos $\quad 36$

6. O que se desvelou a partir do que se mostrou em todo o texto: questionamentos e algumas considerações

6.1 Sobre a regulamentação do atendimento online

6.2 Algumas considerações a respeito da forma de responder do NPPI 59

6.3 Outra possibilidade de compreensão: Orientação online e Plantão Psicológico $\quad 66$

$\begin{array}{ll}\text { Referências Bibliográficas } & 71\end{array}$ 


\section{Apresentação}

Em 1983, um mundo novo se abria para mim. Ao voltar de uma viagem ao exterior a trabalho, meu pai trouxe para casa um Commodore 64, um computador super moderno para sua época. Esse presente foi o meu contato inicial com a tecnologia. Fascinante, era a coisa mais interessante que uma criança, que gostava de montar e desmontar coisas para entender seu funcionamento, poderia imaginar.

O aparelho vinha acompanhado de programas em fita cassete. Era um tempo infindável para carregar qualquer jogo ou executar qualquer comando. Mas isso não me aborrecia. Como alguém maravilhada com tudo aquilo, o tempo passava enquanto eu observava e tentava entender o que mais poderia haver por trás daquelas linhas verdes que apareciam na tela.

Fui crescendo e evoluindo junto aos computadores. Como meu pai trabalhava em área de questão de tecnologia e percebia meu interesse, sempre que possível alimentava minha curiosidade com um equipamento novo, com um software diferente.

Aprendi a usá-los quando ainda era necessário programar comandos. Talvez meu leitor já nem saiba o que isso significa. A linguagem em $\operatorname{DOS}^{1}$, predecessora ao Windows, fazia-me perder horas até conseguir executar o que queria. Mas quando acontecia, era como mágica.

Na chegada do Windows, a vida virou outra. Tudo era muito mais simples, e cada vez mais fascinante. Usava o computador mais para jogos, planilhas e editar textos da faculdade. Era útil, fascinante, mas limitado.

Num universo quase paralelo, bem menos digital, chegava então a minha época de vestibular. Enquanto caminho profissional, sempre me encantei em entender pessoas e seus relacionamentos. A Psicologia foi de alguma forma um caminhar natural daquilo que sempre busquei. Apesar de nesse momento tecnologia e Psicologia não terem nenhum relacionamento e de alguma forma parecerem bem distantes, sabia que a tecnologia para mim poderia ser um complemento, algo que atiçava minha curiosidade, mas não como minha principal motivação profissional.

Em 1994, me apresentaram uma $\mathrm{BBS}^{2}$, e a primeira vez que ouvi aquele barulhinho do modem e vi na tela, em formato DOS, possibilidades de interação com o outro que não estava presente no mesmo espaço físico que eu, novamente me senti encantada. Passava horas

\footnotetext{
${ }^{1}$ DOS- Sistema operacional anterior ao Windows

${ }^{2}$ BBS= bulletin board system- sistema de programas que interligava pessoas e outros programas, próximo ao que faz hoje a internet, só que de forma privativa aos assinantes de um serviço.
} 
explorando, conhecendo, jogando. Fiz amigos ali, alguns que mantenho até hoje. E como quando nos aproximamos de algo, aquilo se torna ainda mais familiar, fui evoluindo junto com essa comunidade, maravilhada com as possibilidades.

Dois anos depois me aproximo da internet comercial recém-chegada ao país, e começa a possibilidade de visitar páginas (sites), além do contato entre pessoas por e-mail, que antes era restrito a poucos, geralmente no meio acadêmico. Seguindo o que considero minha evolução, fui explorar e conquistar esse novo espaço.

Lembro-me de ter feito um caderno com endereços de sites interessantes: aqueles onde poderia voltar mais tarde para continuar alimentando minha curiosidade, uma vez que buscadores de interesse (pesquisa Google) ainda não existiam. Assim, cada página era uma grande conquista.

Mantinha paralelamente a tudo isso, meu interesse por pessoas na internet. Era incrível ver como os relacionamentos surgiam! Como era possível "sentir" o outro e até mesmo compartilhar de sua vida pelas linhas escritas que surgiam em minha tela? Algo que só era compreendido e partilhado por quem vivia nesse universo que até então parecia paralelo.

Findava então o curso de Psicologia na faculdade. Começava uma vida profissional em consultório. Mas constantemente buscava algo para complementar minha carreira e encontrar outras possibilidades de prática psicológica para além das tradicionalmente conhecidas.

No final de 2001, navegando por sites, encontrei uma referência a um site da Psicologia da Pontifícia Universidade Católica de São Paulo (PUC-SP), falando sobre aprimoramento clínico. Ao entrar na página, encontro um serviço chamado Núcleo de Pesquisa da Psicologia em Informática (NPPI). Mais do que qualquer aprimoramento, esse serviço parecia dialogar com aquilo que crescia dentro de mim: alguém além de mim, também interessado em desvendar o que havia por trás "daquelas máquinas" e das relações que se estabeleciam por ela. $\mathrm{O}$ que a Psicologia poderia encontrar nesse novo fenômeno que vinha cada vez ganhando mais adeptos? Seria possível debruçar-se sobre ele e compreendê-lo clinicamente?

Ao me aproximar do serviço, percebi que aquele seria meu lugar por muitos anos. Eram as mesmas ideias, a mesma visão de possibilidades: um mundo de perguntas sem respostas, que precisavam ser construídas na prática. Era um lugar cuja curiosidade primordial perseguia a trilha para possibilidades de buscar compreender as relações humanas mediadas pela tecnologia. Seria possível realizar atendimentos psicológicos pelo computador? Afinal, 
trata-se de um serviço disposto a ouvir uma população que vivenciava uma constante transformação pelas mediações socioculturais contemporâneas?

Posso dizer que a origem deste trabalho de hoje remete à época em que consegui pela primeira vez uma conexão com outra pessoa via computador. Mais do que mágico, aquilo representava um mundo de possibilidades e de contatos sem fim. Unia duas grandes paixões, a tecnologia e pessoas. E era perceptível como elas interagiam em uma sinergia fantástica. Para mim, aquilo era tão natural que nem mesmo conseguia entender como as pessoas questionavam se era possível se relacionar e interagir através da tecnologia. E me perguntava: Só porque foi acrescido um mediador, a relação seria diferente? Os sentimentos são diferentes por que alguma distância física se impõe?

Não é possível sentir-se em contato com o outro por telefone, mesmo sem sua presença física? E as cartas? Não nos abalam positiva ou negativamente dependendo do que o correspondente relata? Será a internet um novo meio de comunicação e proximidade possíveis, como as cartas e o telefone são? Minha história pessoal me remete a conversas sem fim noites adentro na internet, dando a ver como é possível se sentir próximo de alguém distante, por vezes até muito mais próximo do que daqueles que estão ao lado.

A partir de minha experiência como psicóloga surgem questões como: se tais experiências são passíveis de serem vividas, seria possível clinicar pela internet? Se Freud atendia por cartas, poderíamos atender por e-mail (que no consenso em geral se assemelha a um tipo de "carta moderna")? O que poderia ser revelado por esse novo espaço de interação? Como as pessoas se apresentariam por esse modo: seriam elas mesmas? Seriam sinceras da mesma forma que numa situação presencial ou se apresentariam por situações aumentadas ou diminuídas? O que mudaria na relação psicólogo/paciente? Como compreender o setting clínico? Seria possível um estabelecimento de vínculo? Como "tocar" o outro de modo significativo e levá-lo a refletir sobre sua vida?

Só havia um jeito de descobrir tudo isso: viver a experiência. Quando algo novo se apresenta, a única forma de conhecer e compreender é lançar-se à situação. Foi o que fiz. Mergulhei de cabeça, deixando-me inundar por aquilo que via como uma grande possibilidade. E, tocada pela experiência, deixando que a cada mensagem recebida surgissem novas dúvidas, novas certezas e principalmente muitas inquietações.

Para permitir o serviço do NPPI a sobreviver nesse início, travamos muitas discussões. É como se precisássemos provar algo. A sensação que tínhamos, era a de uma necessidade de levantar a bandeira, vestir a camisa e proclamar os benefícios de algo simplesmente porque acreditávamos no que fazíamos. Por outro lado, vendo os e-mails, as mensagens mostravam 
claramente a aceitação do serviço pelos usuários. Mas os psicólogos, de uma maneira em geral, ainda desconfiavam. Pergunto-me se desconfiavam da possibilidade de funcionamento de algo novo ou pelo medo de perder o espaço conhecido do consultório. Será que esse atendimento poderia substituir o presencial?

Acho que por tanto tempo tive de defender o atendimento mediado pelo computador, que um dos maiores e mais difíceis exercícios era o de me permitir questionar. Assim, ia fazendo o que se apresentava ao longo dos anos, como que aprendendo a caminhar antes de poder conhecer o próprio caminho. Este era o modo como aquela equipe tentava desvendar essa possibilidade: na base da tentativa e erro, na experiência, na vontade. Nenhum passo era pensado ou antecipado; ele surgia na medida em que surgia em meio à ação, enfrentando os desequilíbrios surgidos. Talvez, nesse percurso do próprio grupo de trabalho, nunca questionei o caminho, uma vez que a utilização da tecnologia, como possível ferramenta da prática clínica em Psicologia, parecia funcionar dada a experiência vivida: simplesmente ocorria. Mas, com o passar do tempo, e ao mesmo tempo, sentia que faltava algo. Faltava esclarecer esse trabalho que fazíamos, sobre como e o que pensávamos.

Sempre que alguém me perguntava o que eu fazia dentro da Psicologia além do consultório via muitos rostos perplexos. Ao explicar como funcionava e exemplificar os atendimentos mediados por computador, o olhar das pessoas geralmente se transformava. Então, resolvi que era hora de me debruçar sobre esse assunto de forma um pouco mais detalhada, tentando academicamente mostrar aquilo que fazíamos e poder refletir sobre suas possibilidades.

Encontrei muitas portas fechadas. Acredito que a novidade dessa prática leva poucos acadêmicos a encontrar interesse por essa temática. Ainda mais da forma como eu gostaria de pensar o serviço, a partir da experiência.

Foi então que no fim de 2011, encontrei o $L_{E F E}^{3}$ e sua proposta de plantão psicológico. Percebi ali uma possibilidade de abertura e proximidade ao estudo do novo. Encontrei uma nova forma de olhar o mundo que me fez refletir e validar minha experiência. Assim, em 2013 resolvi cursar o mestrado e me aventurar na narrativa desta que tem sido uma experiência profissional bastante criativa. Uma criatividade partilhada entre aqueles que faziam e fazem parte do NPPI, que se desdobram na experiência, no encontro de ideias e ideais.

\footnotetext{
${ }^{3}$ Laboratório de Estudos em Fenomenologia Existencial e Prática em Psicologia da Universidade de São Paulo
} 
E para refletir acerca do que faço como faço, escolhi um caminho passando pelas seguintes veredas: - primeiro situar a questão do desenvolvimento da tecnologia e sua influência na Psicologia; - apresentar o serviço do qual faço parte (NPPI); - apresentar os questionamentos do Conselho de Psicologia e sua compreensão acerca desse modo de atendimento online; - para poder buscar uma melhor forma de compreensão do atendimento mediado pelo computador, como metodologia, recorro à narrativa de um processo a partir de mensagem recebida; por último, um olhar analítico sobre essa mensagem e possível abertura para um novo tipo de resposta, considerará questionamentos por ela suscitados. Com isso, e através disso, buscarei refletir acerca da ação nessa modalidade de prática psicológica ainda em construção. 


\section{Introdução}

\subsection{Tecnologia e Psicologia}

Para melhor compreender a possibilidade da orientação online, faz-se necessário uma aproximação com a história do desenvolvimento da tecnologia e sua devida aproximação com a Psicologia. Baseio-me no artigo de Leitão \& Nicolaci-da-Costa (2001). As autoras traçam o paralelo entre o surgimento dos computadores e o efetivo uso pela população em geral até o interesse dos psicólogos tanto nos Estados Unidos como no Brasil.

Iniciamos falando primeiro de Estados Unidos. Nesse país, o desenvolvimento da tecnologia tem início na década de 40 , sendo que a construção da tecnologia era desenvolvida para uso militar. Por conta da Segunda Guerra Mundial e da Guerra Fria, conhecimentos acerca da tecnologia de computadores eram cercados de mistério. Isso levava a população em geral a ter muito receio a respeito das máquinas ainda mais alimentadas pela ficção científica escrita na época que trazia a ideia de máquinas inteligentes que substituiriam o ser humano (a título de exemplo Admirável Mundo Novo, de Aldous Huxley, reeditado em 1946) e a sensação de tudo ser vigiado e controlado (1984 de George Orwell publicado em 1949). Assim as décadas de 40, 50 e 60 são marcadas por pessimismo e desconfiança frente a computadores, uma vez que tudo que se constrói a respeito do assunto, ocorre a portas fechadas.

Já na década de 70 a meados de 80 , começa a haver um interesse em colocar no mercado civil o uso de computadores. E assim, as empresas já disponibilizam para uso profissional seus aparelhos e a população tem tempo para se familiarizar com eles. Mas é na década de 90 que surge a internet civil. Antes disso, a ARPANET- rede interligada de computadores surgida na década de 60 - era apenas utilizada para fins científicos e militares. A abertura da internet para a população em geral e o surgimento da World Wide Web modificam a forma de se entender e se utilizar a internet.

Assim, as pessoas são impulsadas pela curiosidade a utilizarem seu tempo de lazer nas atividades disponibilizadas pela rede, como por exemplo, em bate papos e pesquisas. Algumas pessoas começam a cometer excessos online, o que atrai a atenção dos psicólogos que começam a pesquisar e publicar sobre o assunto.

Mas, para poder compreender o interesse por essa tecnologia e qual o seu significado para os homens, faz-se necessário, primeiro, compreender esse espaço (o virtual) no qual ela se dá. O espaço virtual não tem nada de irreal como demonstrado por Levy (1996, p. 15): 
A palavra virtual vem do latim medieval virtualis, derivado por sua vez de virtus: força, potência. Na filosofia escolástica, é virtual o que existe em potência e não em ato. $\mathrm{O}$ virtual tende a atualizar-se sem ter passado, no entanto, à concretização efetiva ou formal. O possível já está todo constituído, mas permanece no limbo. O possível se realizará sem que nada mude em sua determinação nem em sua natureza. É um real fantasmático, latente. O possível é exatamente como o real: só lhe falta a existência. A realização de um possível não é uma criação, no sentido pleno do termo, pois a criação implica também a produção inovadora de uma ideia ou de uma forma.

Assim, o virtual torna-se real à medida que as experiências de comunicação não se configuram como meras imagens e símbolos, mas sim como meio de comunicar sentimentos e sensações, como dito por Levy ( 2005, p. 49) “O virtual existe sem estar presente”, dando a entender que o contato humano via tecnologia transcende o computador. Nas palavras de Donnamaria \& Terzis:

Não por acaso, o termo virtual parece vir caindo em desuso nas referências aos relacionamentos mediados pela internet, sendo substituído pelas expressões on-line e à distância. Isso, a nosso ver, expressa uma conscientização de que pessoas reais se encontram e se afetam no ciberespaço, cada qual com o seu computador, independentemente do lugar físico onde cada uma delas esteja (DONNAMARIA; TERZIS 2012, p.6).

Nessa direção, podemos agora situar alguns trabalhos iniciais na área da Psicologia que se apresentaram a partir desses questionamentos. Leitão \& Nicolaci-da-Costa (2001 p. 10) citam:

Em 1998, em matéria de capa do seu numero de março, o APA Monitor, jornal da American Psychological Association confirmava o interesse dos psicólogos pelos impactos da Internet e divulgava vários livros e um periódico, todos dedicados a investigação desses impactos. Os livros mencionados pelo APA Monitor, por ordem de data de publicação, são: Life on the screen: identity in the age of the Internet, de Sherry Turkle (1995); TechnoStress, de Michelle Weil e Larry Rosen (1997); Data smog: surviving the information glut, de David Schenk (1997); Tendencies and tensions of the Information Age, de Jorge Reina Schement e Terry Curtis (1997); What will be: how the new world of information will change our lives, de Michael Dertouzos (1997); e Caught in the Net, de Kimberly Young (1998). O periódico e a revista CyberFsychology and Behavior.

No Brasil, durante as décadas de 50 e 60 houve pouco investimento em relação ao desenvolvimento de computadores. Tinham acesso à tecnologia apenas as pessoas de elite ou alto escalão de empresas; em contrapartida, a literatura de ficção cientifica sobre o assunto permeava o cotidiano, contribuindo para a criação de muitas fantasias a respeito da temática.

Na década de 70, o país decide investir na criação de tecnologia nacional, limitando a importação. Assim, durante as próximas duas décadas acontece uma grande defasagem em 
relação a outros países. Enquanto nos Estados Unidos já havia micro computadores, no Brasil predominava os de grande porte. Por consequência dessa falta de contato, o imaginário brasileiro continua permeado de pessimismo e da sensação de controle, provocados pela literatura.

Em 1990, com as grandes mudanças políticas ocorridas no País, a importação passa a ser liberada e é nesse momento que o Brasil entra na era digital. Simultaneamente à chegada dos computadores abre-se o uso da internet, sendo que de 1988 a 1991 restringe-se para uso em universidades e em 1995 expande-se para uso comercial. Sendo assim, o uso da tecnologia e a conectividade acontecem aqui praticamente ao mesmo tempo, não dando à população a possibilidade de familiarizar-se gradativamente com essas facilidades tecnológicas do mesmo modo como ocorrera nos Estados Unidos.

Mas apesar dessa diferença na forma de aproximação, o interesse da população e o tipo de uso que começou a ser efetivado eram praticamente o mesmo. Contudo, os excessos cometidos e a novidade traziam, ao mesmo tempo, interesse e medo de prováveis usuários. É por essa época que a situação de excesso no uso e desconhecimento de possíveis consequências leva também no Brasil a um movimento de compreensão dessa tecnologia e consequente interesse pelas possibilidades de utilização deste meio por parte de psicólogos.

O Conselho Federal de Psicologia, percebendo o interesse da classe dos psicólogos, promove então, em 1998, o primeiro seminário relativo ao tema para discussão entre os profissionais e reflexão sobre modos de emprego pelos psicólogos. É nessa época que alguns profissionais começam a fazer uso instrumental da internet, aparecendo os primeiros atendimentos psicoterápicos online no país, frente a possível potencialidade oferecida por essa tecnologia. Paralelamente, é formado um grupo de trabalho (GT- ATMC ${ }^{4}$ ) por psicólogos interessados nessa área para pensar e criar normatização aos atendimentos que já vinham acontecendo.

Em setembro de 2000, é promulgada a primeira regulamentação $\left(\mathrm{n}^{0} 003 / 2000\right)$ relativa a atendimentos mediados pelo computador pela internet. Por ela, fica estabelecido que não se pode realizar psicoterapia através da internet sem que seja para fins científicos e que seja explicitado seu caráter experimental. Conforme artigo 5, orientações ficam liberadas:

Art. 5o. São reconhecidos os serviços psicológicos mediados por computador, desde que não psicoterapêuticos, tais como orientação psicológica e afetivo-sexual, desde que pontuais e informativos, orientação

\footnotetext{
${ }^{4}$ Grupo de Trabalho de Atendimentos Mediados por Computador formado pelo Conselho Federal de Psicologia com o intuito de compreender melhor a prática que estava sendo delineada.
} 
profissional, orientação de aprendizagem e Psicologia escolar, orientação ergonômica, consultorias a empresas, reabilitação cognitiva, ideomotora e comunicativa, processos prévios de seleção de pessoal, utilização de testes informatizados devidamente validados, utilização de softwares informativos e educativos com resposta automatizada, e outros, desde que não firam o disposto no Código de Ética Profissional do Psicólogo e nesta Resolução, e garantidas as seguintes condições.

Além disso, para poder realizar orientações online, o psicólogo deveria ter um site próprio, no qual constaria um selo do Conselho Federal informando ter sido aprovado para tal finalidade.

Essa resolução tem prazo de 5 anos, após o que é revista. A revisão ocorre em agosto de $2005\left(\mathrm{n}^{0} 012 / 2005\right)$ sem apresentar grandes mudanças em relação à anterior. Contudo, em $2012\left(\mathrm{n}^{0} 11 / 2012\right)$, após a realização de vários simpósios regionais e nacionais, é elaborada uma nova resolução, apresentando algumas mudanças em relação ao que é permitido e como é compreendido o atendimento online. Por ela, a psicoterapia continua sendo proibida, a não ser em caráter experimental. Já sobre a orientação, a resolução diz:

Art. 10.

São reconhecidos os seguintes serviços psicológicos realizados por meios tecnológicos de comunicação a distância desde que pontuais, informativos, focados no tema proposto e que não firam o disposto no Código de Ética Profissional da(o) psicóloga(o)e esta Resolução:

I. As Orientações Psicológicas de diferentes tipos, entendendo-se por orientação o atendimento realizado em até 20 encontros ou contatos virtuais, síncronos ou assíncronos;

II. Os processos prévios de Seleção de Pessoal;

III. A Aplicação de Testes devidamente regulamentados por resolução pertinente;

IV. A Supervisão do trabalho de psicólogos, realizada de forma eventual ou complementar ao processo de sua formação profissional presencial;

V. O Atendimento Eventual de clientes em trânsito e/ou de clientes que momentaneamente se encontrem impossibilitados de comparecer ao atendimento presencial.

Parágrafo Único: Em quaisquer modalidades de serviços, a(o) psicóloga(o) está obrigada(o) a especificar quais são os recursos tecnológicos utilizados para garantir o sigilo das informações e esclarecer o cliente sobre isso.

Importante ressaltar que, durante todo esse processo, o NPPI, que será em seguida apresentado, esteve participando ativamente, uma vez que já se preocupava com a temática e vinha realizando orientação online. Entretanto, sendo muito tênue a diferenciação entre psicoterapia online e orientação, tal questionamento estará presente em todas as considerações que aqui serão apresentadas. Embora pouco possa ser discutido acerca dessa diferença, PRADO (2000) apresenta que psicoterapia online é uma comunicação entre pessoas, na qual uma delas tem o papel de profissional de saúde mental, assim assemelhando-se a um 
atendimento presencial, enquanto para FORTIM (2004), a orientação online visaria versar sobre um assunto específico que se encerraria no próprio e-mail ou em um número limitado de sessões, propiciando ao cliente buscar auxilio para encontrar um atendimento presencial.

\subsection{O Núcleo de Pesquisas da Psicologia em Informática (NPPI)}

Criado em 1995 a partir de discussões dos professores Rosa Maria Farah, Lourival de Campos Novo e Ruth Lopes, o NPPI tem como função inicial criar uma home page para a comunicação da clínica de Psicologia com outras instituições e também para a informatização do Boletim Clínico, uma publicação de pesquisas da Clínica Psicológica da PUC. Nessa época, a internet era restrita aos meios acadêmicos, mas logo foi possível perceber a velocidade de desenvolvimento desse meio, e então se amplia o trabalho do NPPI para a divulgação de ensino e pesquisas realizados na faculdade de Psicologia da PUC assim como para a apresentação dos serviços a população em geral.

Para sua primeira versão a ser lançada, a página da Clínica da PUC contou o apoio informal da chefia da clínica e com o apoio de Tatiana e Alexandre Dowbor, donos de uma BBS chamada PsicNet e que hospedaram inicialmente o conteúdo. Posteriormente, o material foi transferido para os servidores da PUC.

Paralelamente a isso, o interesse da população em geral crescia a respeito das mídias digitais. A velocidade exponencial do crescimento da tecnologia toma a todos de surpresa, abrindo novas possibilidades de atuação. O Conselho Federal de Psicologia resolve então intervir e de alguma forma regulamentar as possibilidades de atuação. Falo dessa intervenção mais a frente.

Em outubro de 1998, é realizado o primeiro Psicoinfo com promoção do conselho federal de Psicologia, evento onde alguns objetivos do NPPI se delimitam. São eles: 1Implementar a informatização da comunicação clínica escola e a comunidade; 2- implementar projetos de reflexão e pesquisa visando investigar do ponto de vista psicológico os efeitos gerados pela difusão dos recursos da informática nos diversos campos de atividade humana; 3- implementar o desenvolvimento de serviços psicológicos informatizados.

Na página principal do serviço, constava um e-mail de contato, justamente para esses fins mencionados acima. A equipe, composta pelos professores e dois estagiários voluntários, visava responder essas questões e alimentar os conteúdos teóricos da página. Já o fluxo de mensagens recebidos no e-mail, era pequeno e normalmente dizia respeito ao funcionamento da clínica, eventualmente algum contato com um professor. 
No meio de 1998, começaram a chegar mensagens, que inquietaram a equipe. Eram emails de cunho pessoal, nos quais a pessoa que escrevia relatava um problema que estava vivenciando e pedia uma orientação sobre como conseguir ajuda para tal questão. Embora tal situação não contemplasse a ideia inicial de um espaço exclusivo para comunicação acadêmica, a equipe começou a questionar o que fazer com tais mensagens. Ignorar?

Contudo, como o serviço fazia parte de uma clínica de Psicologia, lugar procurado por pessoas buscando ajuda, tais pedidos deveriam ser excluídos? Isso não seria negligência por parte da equipe de psicólogos? Mas como responder a essa pessoa? Seria esse um espaço possível de ajuda? À medida que os e-mails chegavam, pensava-se em quais seriam os preceitos básicos para um atendimento presencial, e quais seriam necessários para uma via de comunicação online. Desse modo, foi construída uma mensagem, personalizada e individualizada para cada e-mail recebido.

Passado algum tempo, foi possível observar que à medida que as pessoas começavam a usar a internet, elas também começavam a se apossar de ferramentas como o uso do e-mail e a ter suas vidas permeadas por esse uso (NOVO, 2004; COSENTINO, 2006), e este vinha se tornando um canal possível para pedir ajuda. Por essa época, a profa. Ruth Lopes se afasta da equipe, mas Rosa e Lourival decidem ver quais as possibilidades ali existentes, e o que fazer com esses pedidos que começam a se mostrar.

Em março de 1999 começa a ser oferecida a possibilidade de estágio no NPPI. A equipe é composta por psicólogos formados que ingressam no aprimoramento clínico da clínica psicológica da PUC-SP, e escolhem entre as opções obrigatórias de serviço o NPPI. Após o término desse período, por ser um serviço muito específico, aqueles que desejam continuar se tornam auxiliares voluntários. A equipe vai se expandindo à medida que o núcleo vai se caracterizando como serviço. Atualmente ela é composta por uma coordenadora e nove psicólogos.

O serviço recebe e-mails espontâneos e, portanto, com diferentes conteúdos que foram pedindo adaptações. Inicialmente realizava-se apenas aquilo que atualmente denominou-se como orientação geral ou pontual. Tal nome é dado na tentativa de diferenciação de outros atendimentos que aparecerão posteriormente: Atendimento a uso compulsivo de internet e Orientação Estendida. Mais adiante serão abordados mais detalhadamente.

Há outras atividades realizadas ainda pelo NPPI, conforme descritas por Farah (2004). Delas destacam-se: atualização e manutenção da página do serviço, oferta de estágio a psicólogos que queiram estudar a área, desenvolvimento e supervisão de novas modalidades de serviços psicológicos informatizados (orientação via e-mail em especial), atender usos 
excêntricos ou patológicos relativos à tecnologia, oferta de disciplina na graduação da Faculdade de Psicologia da PUC, orientação à comunidade através de palestras e entrevistas a imprensa, pesquisa e reflexão acerca dos efeitos da difusão da tecnologia, participação junto a órgãos de classe na discussão de serviços psicológicos mediados pelo computador, além de uma coluna eletrônica em um site abordando o assunto para a população em geral.

\subsection{Questionamentos para encaminhar uma reflexão}

Fica a questão que tem me norteado: Como faço o que faço? Qual o sentido desse trabalho? Como esclarecer a alguém que tipo de atendimento é esse? Existem particularidades nesse tipo de atendimento? 


\section{Objetivos:}

\subsection{Geral:}

Dar a ver possibilidades de realização de atendimento online

\subsection{Específicos:}

- $\quad$ Apresentar como acontece a procura pelo serviço;

- $\quad$ Apresentar possibilidade de resposta para um atendimento online;

- Compreender como poderia ser uma abertura de possibilidades para esse atendimento, considerando a análise de atendimento online apresentado. 


\title{
4. Metodologia
}

Considerando-se por metodologia sua origem grega como meta (além) + hodos $($ caminho $)+\operatorname{logos}($ dizer $)$, enveredo pelo percurso de como o caminho poderá ir se dizendo na medida do próprio caminhar. Amparo-me em Critelli (2012, p. 19): “O que apresento neste pequeno livro é tão somente o perfil de um caminho metodológico. Não farei uma descrição e análise da prática dessa metodologia, nem tratarei dos instrumentos criados para sua aplicação."

Nessa mesma direção, perseguir um modo fenomenológico existencial de pesquisar implica compreender que aquilo que acontece durante o desenrolar da pesquisa se constitui no encontro entre sujeito, mundo e outros. Tal articulação somente poderá ser compreendida pela própria condição humana de mútua afetação e interpenetração: o pesquisador passa a ser narrador da experiência vivida entre ele e outros, considerando-se que, a ele, abre-se como factível apenas uma das interpretações possíveis do real; quer dizer, "não é uma façanha lógico-conceitual, mas uma possibilidade de compreensão”, como aponta Critelli (1996, p. 136).

Acompanhando Arendt, Critelli (2012, p. 24) apresenta que o pensar, como reflexão, é um modo de o humano encontrar-se em sua existência. Assim,

\begin{abstract}
O pensar é compreensão quando sua finalidade é o entendimento do sentido de algo ou de uma situação para que possamos lidar com eles. É próximo do pensamento, propriamente dito (e que a filosofia realiza), enquanto sua estrutura é reflexiva, mas distingue-se dele à medida que o resultado da compreensão interessa imediatamente à ação, portanto à vida cotidiana e em conjunto. É uma atividade que não é de competência apenas do filósofo, nem só do cientista, mas uma exigência do próprio existir como homens, à medida que incapazes de agir sem compreender (p. 24).

Diante de eventos inusitados, que abalam nossa forma cotidiana e habitual de entender e ser, sentimo-nos perplexos e paralisados, como se tivéssemos perdido nosso lugar no mundo. É aí, propriamente, que a compreensão começa (p.25).
\end{abstract}

Nesse sentido, a compreensão confere sentido ao que lhe vem ao encontro, inclusive encontrando referendo no senso comum, como aquele conhecimento compartilhado na coexistência entre homens (a cultura), dizendo respeito ao que pode orientar o agir cotidiano. A compreensão revela-se o solo compartilhado a partir do qual as experiências recebem significação e as possibilidades de ação surgem irrefletidamente.

Isso quer dizer que a vida cotidiana pode não depender da sabedoria dos filósofos, mas depende da compreensão de cada indivíduo e daqueles com os 
quais ele convive para ser empreendida: o que considerar certo ou errado, necessário ou obsoleto, que profissão escolher, como ser feliz, em quem e no que acreditar... O empreendimento do existir diário depende mais da compreensão do que da filosofia. (CRITELLI, 2012, p. 27)

Desse modo, os eventos da vida cotidiana que conduzem nossa existência precisam ser arrumados em uma história para que seja possível compreendê-los como fatos para podermos levar adiante nossas ações. É pela linguagem que tais acontecimentos podem ser narrados permitindo que o mundo vivido possa ser habitado.

Pela linguagem nos introduzimos no mundo, consequentemente, na existência. Pela linguagem temos acesso ao real, aos outros e a nós mesmos. A linguagem é nossa ferramenta de existir e, ao mesmo tempo, nosso solo. É nosso meio e nossa condição. É nosso destino. (CRITELLI, 2012, p. 33).

No entanto, imersos nos afazeres e ocupações do cotidiano do viver, pouco nos debruçamos para poder compreender quem somos através de nossas ações. Geralmente são os outros que compartilham da existência conosco que, mais distanciados, podem dizer de nós. Assim, somos mais atores do que narradores.

Ser narrador de si mesmo é um árduo aprendizado. Porque age e fala sobre o que faz, o agente dos atos se ilude quanto a poder narrar-se. Ser agente dos próprios atos e falar deles é apenas o primeiro nível em que transcorre nosso existir. O segundo nível é poder ser expectador de si mesmo, de seu agir. O terceiro é narrar-se. O quarto é aquele para onde a narração nos conduz: podermos julgar a nós mesmos, mediante análise e reflexão sobre o alcance e as consequências de nosso agir sobre os outros e sobre o mundo em que vivemos. (CRITELLI, 2012, p. 38).

Se a experiência que pretendo discutir nesta dissertação diz respeito ao atendimento psicológico através de e-mails, e sendo que esta forma de correspondência ocorre através da internet (espaço virtual), uma possibilidade metodológica pertinente poderia ser percorrer o caminho da experiência. Acompanhando Morato (2009, p. 34),

"Não existindo certeza de encontrar-se res-pondendo no mundo, resta ao profissional encontrar-se a si mesmo, dentre a multiplicidade de possibilidades de respostas, qual a que seja mais apropriada a sua forma de ser, através de encontrar-se, com sua compreensão e com sua fala, na experiência...".

Caminhando nessa direção, mas por outro enfoque, a metodologia do depoimento como registro da experiência origina e embasa a possibilidade de análise de uma pesquisa 
interventiva perseguindo a experiência do próprio pesquisador. De acordo com Schmidt (1990, p. 79), a "qualidade de recolhedor da experiência ancora-se no trabalho do pesquisador-escritor, envolvido na busca da alteridade e compromissado com a invenção da linguagem que comunique o encontro - suas vibrações, suas aberturas, seus silêncios."

Desse modo, a execução de uma ação assim direcionada significa elaborar uma narrativa da experiência, buscando compreensão. A apresentação do acontecimento é uma forma de re-contar a si e a outros a história que foi vivida e contada, de forma que pudesse dela se apropriar com outro sentido.

Nesse sentido, o que fazemos e dizemos dizem de nós, mas seu significado também se dá a ver na medida em que os outros nos testemunham para apresentar um acontecimento que se apresenta em discurso.

O mesmo acontece com as palavras. Sem um ouvido que as acolha e reconheça, restam como simples balbuciar, mero ruído. Gestos e palavras são produções coletivas.

O que um indivíduo faz e diz não depende só dele, mas dos outros que o testemunham e interagem com ele. Os gestos que costumamos chamar de meus são, na verdade, nossos. (CRITELLI, 2012, p. 61).

É nessa direção que o caminho a ser seguido como metodologia percorrerá a história da pesquisadora através de sua experiência, para que sua singularidade de buscar compreender “como faz o que faz" possa perceber a autoria de seu fazer. Para Critelli (2012), é esse o foco da Historiobiografia, cujo "meio é o aprendizado de ser expectador e narrador de si mesmo." (CRITELLI, 2012, p. 40), procurando o fio de sentido que possa alinhavar os eventos vividos na construção de um percurso.

Nas palavras de Critelli (2012, p. 101),

Enfim, interessa à Historiobiografia a recuperação da história da história pessoal através das narrativas nas quais os indivíduos, plurais e singulares, acondicionaram, preservaram, salvaram e projetaram sua existência pessoal e seu destino e na qual escreveram o sentido da vida. Afinal, e aí a maior importância das narrativas, a vida humana é embrulhada na linguagem, é um fenômeno de linguagem.

E em falando em linguagem, a questão do atendimento online se apresenta como acontecimento pelo qual o fio de sentido da existência se mostra por palavras escritas e testemunhadas por outro através de sua compreensão também por palavras escritas. Seria um evento pelo qual ambos os interlocutores se encontram pelo modo como se dizem e 
compreendem seu agir: uma possibilidade de caminho para investigar "como faço o que faço"? 


\section{Algumas mensagens recebidas}

Comecei a questionar alguns pontos da orientação online após meu ingresso no mestrado. É como se enquanto parte do grupo do NPPI, também estivesse mergulhada e permeada por esse modo de fazer, como se fosse uma receita a ser seguida. Uma das questões que me fez pensar sobre isso foi: como responder a um e-mail de orientação?

Minha resposta acompanhava a seguinte experiência: ao receber uma mensagem, após anos no serviço, quase que instintivamente o sentido e a resposta brotam. Seria o senso comum do qual Critelli (2012) fala?

Apesar do conteúdo pessoal, a mecânica das respostas usadas no NPPI pode ser descrita rapidamente: acolher, buscar tema central, tocar em questões que parecem mobilizar o paciente, sugerir reflexão e a possibilidade de um desdobramento da orientação se necessário. Teria então esse trabalho se transformado em algo mecânico, em uma técnica? Teria se perdido a questão da prática em construção e se acatado um lugar designado por outrem? Teria o grupo se enrijecido ou seria uma questão pessoal minha?

Quanto aos atendimentos, também questionamentos surgem. Será que há uma única forma de conduzir atendimentos online? Precisariam ser encaixados em normas e modelos, e não serem terapêuticos, como dito pelo Conselho? Como ser uma orientação não terapêutica e não se tornar psicoterapia? Não haveria um lugar de fronteira entre eles?

Por outro lado, essas questões também estão implicadas no modo de se responder a um e-mail. Há um processo de análise que ocorre por trás de cada resposta? Como uma resposta é construída? O que se leva em conta no momento da criação? O que seria levado em conta na hora de criar uma resposta do jeito como acontece nesse serviço? Mas, sendo um atendimento online, ele ocorre de forma diferente do atendimento presencial? Procederia um cuidado maior por tratar-se de mensagem escrita? Seria um novo modo de trabalho do psicólogo?

Para trilhar esse caminho de tantos questionamentos, escolhi um conjunto de mensagens que mobilizou a equipe para tentar compreender como ocorre o processo de orientação online. Esses e-mails também foram escolhidos pela riqueza de questionamentos que proporcionou. Apresentam diversos pontos sob os quais é possível lançar o foco de atenção e refletir a partir do que se apresenta na prática.

A fim de permitir uma melhor compreensão, coloco as trocas de mensagens intercaladas: primeiro cliente, depois NPPI e assim sucessivamente. Após todas as 


\title{
mensagens, ensaiarei uma análise clínica dos e-mails recebidos ${ }^{5}$. Opto aqui por não analisar as mensagens enviadas pela equipe.
}

\author{
4 de agosto 2013678
}

Gostaria de receber a orientação online.

Há mais ou menos 1 ano e meio conheci o serviço oferecido por vocês através de um amigo que realizou um projeto de pesquisa sobre esse tema. Desde essa época penso quase todos os dias em thes enviar um e-mail. Por mais simples que pensei que fosse de escrever, por se tratar de um contato virtual, não está sendo tão fácil assim. Mas agora estou decidido a ir em frente.

O que acontece comigo é o seguinte: já fiz terapia por diversos anos (contando tudo uns 11 anos, nas abordagens comportamental, transpessoal, rogeriana e fenomenologia), e tem coisas que nunca consegui conversar pessoalmente, por medo de ser julgado lo que ela vai pensar de mim), ou por não conseguir mesmo, eu vou na terapia pensando assim - dessa vez vou falar - mas nunca sai e estou na mesma há muito tempo. Namoro há 6 anos, tem 6 anos que quero terminar, ficar solteiro de novo (tenho 34 anos agora), mas tenho de medo de arrumar uma namorada pior que a atual (que é meio infantil, grita comigo, não sabe conversar, quer tudo do jeito dela, etc), e nem isso consigo resolver, não desapego nem por reza brava...

Mas voltando ao ponto, também sou viciado em assistir vídeos de sexo pela internet, $e$ atualmente estou assexuado em relação a minha namorada, não quero nem chegar perto, $e$ quando transo sem camisinha, me dá uma coceira no pênis (tá aversivo a coisa), não gosto do cheiro dela, tá tenso!!! E na internet é aquela bizarrice... o ângulo da câmera tem de ser perfeito, com a vagina perfeita, posição que me agrade, senão nem assisto... até a tonalidade de pele da mulher interfere... E pra piorar (aí que não dá pra conversar com minhas psicólogas) é que tive uma fixação por strapon (aqueles pênis de borracha que a mulher usa), e fiquei assistindo várias vezes esse tipo de vídeo... até que não sei como minha namorada topou usar isso, no início eu gostava dela me comer, mas até isso hoje não me satisfaz (com ela), eu

\footnotetext{
${ }^{5}$ Serão mantidos tanto a forma quanto os erros de grafia e gramaticais dos e-mails originais por acreditar que muitos deles apresentam um pouco da forma de expressão do cliente.

${ }^{6}$ Em azul, a mensagem do cliente; em vinho, a mensagem do NPPI.

${ }^{7}$ As datas foram alteradas para preservar a confidencialidade

${ }^{8}$ A autorização para uso dessas mensagens em estudo cientifico foi dada através de nota acrescida em todos os e-mails enviados pelo NPPI com os seguintes dizeres: "As orientações oferecidas pelo NPPI são realizadas de acordo com as normas da Resolução 11/2012, do C.F.P., e do Código de Ética de Psicologia. O NPPI, como serviço da Clínica da PUC-SP, tem também os objetivos do ensino e pesquisa em Psicologia. Assim, os dados colhidos poderão ser utilizados para fins didáticos, de pesquisa e publicações científicas. Asseguramos que essas informações são tratadas de forma absolutamente confidencial, de maneira que nenhum dado de identificação das pessoas atendidas é divulgado. No entanto, caso não concorde que os seus dados façam parte dos nossos estudos, envie mensagem informando do contrário". O cliente ainda conta (nas trocas de e-mails aqui apresentadas) ter visitado o site do NPPI (http://www.pucsp.br/nppi/orientacao_email.html), onde tal termo de ciência/anuência também se encontra presente.
} 
fantasio transando com outras mulheres dos vídeos. Pra piorar mais ainda, começei a ver vídeos com shemales (travestis), e volta a questão acima, tem de ser uma travesti perfeita, a cena perfeita, senão não dá... e só gosto de ver a travesti comendo o homem (que não pode ser afeminado, senão também não gosto).

Ai li na internet algo um dia que falava resumidamente assim: se o homem tem tesão nessa questão do pênis, e tem de ser tudo perfeito e talz, sem contato intimo, não tem nada a ver com homossexualidade (antes eu tinha medo de ser gay, mas tentei assistir alguns vídeos pra tirar a dúvida, e não senti tesão nenhum, nem nojo, só não achei graça), e sim com uma questão com o pai mal resolvida... ai explicava um pouco mais, e depois de ler isso, fiquei um mês sem querer usar o tal do brinquedinho... aî hoje de vez em quando usamos, mas a questão tá mudando de figura, hoje tô vendo que não tenho tesão nenhum na minha namorada, que só fala em casar, 24 horas por dia, me pressionado, falando que termina se não casar, e tá muito foda, tô vivendo um estresse muito grande, pois tenho medo de terminar e começar tudo de novo, já namorei outra vez antes por 6 anos, ela me traiu, terminamos, fiquei muito mal, depois melhorei, fiquei com poucas garotas, e começei a namorar com essa...

Dai o que penso sempre é que tive poucas garotas na minha vida, e que as poucas que tive era bom demais no início (na questão sexual), aquela descoberta, tirar a roupa, sentir o corpo... e hoje não tenho mais isso... (tive isso os 6 anos que namorei com a outra, que me traiu, nela sentia um tesão incrivel)...

Mudando de assunto, quando eu tinha 16 ou 17 anos, tinha saido do colégio e estava estudando pro vestibular, não sabia o que fazer da vida, tinha um amigo de uma menina que eu era apaixonado, e fiquei apaixonado uns 6 anos, minha amiga até hoje... Só que esse amigo dela era gay, e resumindo, um dia voltando de uma festa, trêbado, e depois de fumar maconha, meio que transamos (se pode-se dizer isso)... eu deixei ele me comer num beco... $e$ doeu demais da conta, ficou doendo uns 15 dias... Eu fiquei mal demais, ele ficou me ligando, eu fugi e nunca mais aconteceu nada... Só que durante muito tempo eu fiquei com medo de ter me tornado gay pq tive um fato desses... até que deixei pra lá. Só que nem esse tipo de coisa jamais consegui contar pra psicóloga alguma (tive várias)... e minha dúvida é: se eu contasse ajudaria alguma coisa no meu caso? Pois eu faço terapia até hoje e não consigo resolver minha vida, terminar o namoro que (apesar de ter seus pontos bons, digo com isso: estou na minha zona de conforto), mas tem muitas coisas que não são boas, não gosto de brigas, de não ter amigos, pois ela me barra de todo jeito, eu acabo só ficando em casa, no videogame ou internet, e sinto muita falta de amizades... Só que de outro lado, com 34 anos, como vou fazer amigos? o pessoal do meu trabalho são meus amigos, mas são todos casados... não tenho ninguém aqui pra sair na balada, vou acabar ficando mais frustrado ainda, ter de ir no fundo de carreira que são os puteiros dessa cidade... Fico TODO DIA NESSE DILEMA...

Nesse mesmo tema, antes disso acima acontecer, eu já tinha essa fixação anal, e como era adolescente, o que fazia era pegar uma cenoura, camisinha e enfiar lá... só que um belo dia, eu joguei isso no lixo de casa (na verdade um lixo grande de fora da minha casa), dentro de um saco preto, e minha mãe enxerida abriu isso e veio me perguntar o que era... Cara, eu já 
era estressado e brigava muito com minha mãe por ela invadir meu espaço, isso aí é uma coisa que me deixou muito sem graça... só pra constar...

E na minha primeira transa, em Porto Seguro, viagem do terceiro ano, que perdi a virgindade com uma mulata, numa pousada... foi tenso, porque ela colocou a camisinha com força, ai doeu, broxei e fiz sem camisinha mesmo depois, só que pra piorar ela falou que meu pênis era pequeno (muito tempo fiquei bolado com isso), ele tem uns $13 \mathrm{~cm}$ (depois que emagreci), e não sei se é um número bom ou não, mas hoje acho que sim... estou tranquilo quanto à isso, agora minha dúvida é em relação à grossura...

Tá vendo, eu nunca na minha vida ia conseguir falar isso presencialmente, nem por skype...

Espero que eu consiga uma luz com vocês...

Obrigado!!!!

14 de agosto de 2013

Olá,

Realmente não é fácil a gente expor nossos maiores segredos, medos e desejos para uma outra pessoa. Mas que bom que você teve a coragem e conseguiu dar esse importante passo! Muitas vezes, quando não falamos algo, aquilo fica nos atormentando, assombrando e vai ganhando cada vez mais força... parece que não dividir, ao invés de fazer sumir, só faz crescer a dúvida e o sofrimento.

Parece que boa parte de seus questionamentos passam pela questão sexual: você conta que está com dificuldades sexuais importantes na relação com sua namorada ("não quero nem chegar perto, e quando transo sem camisinha, me dá uma coceira no pênis (tá aversivo a coisa), não gosto do cheiro dela, tá tenso!!! "), conta que tem inseguranças com relação ao tamanho e grossura de seu pênis, já ficou confuso com relação a sua orientação sexual, entre outras questões.

A sexualidade é mesmo um campo de nossa vida que, geralmente, além de todo o prazer, traz muitas dúvidas, inseguranças, tabus. Você parece exigir da relação sexual um nível de perfeição que, muitas vezes, é difícil alcançar. Quando está vendo pornografia ou imaginando, fica fácil manter esse nível de perfeição e controle, mas quando passa para a vida presencial, na hora mesmo da relação, não existe essa transa ideal. Talvez por isso, no início de seus relacionamentos, as relações são muito boas e, depois, vem uma certa frustração.

Outro ponto importante é marcar a diferença entre desejar alguém do mesmo sexo e ter prazer na zona erógena anal. Você sentir prazer anal não quer dizer que você tenha desejo por outros homens. Mas parece que isso você já descobriu! Testando tanto uma relação propriamente dita, como assistindo vídeos homossexuais. 
O que ficamos pensando ao ler seu email é que seu prazer não tem relação com os homens e sim, com mulheres poderosas. Ao se deixar penetrar por uma mulher, além do prazer físico da penetração anal, você está sentindo prazer por se submeter a uma mulher... isso não é errado nem certo se ficar apenas ligado ao momento da transa, o problema é que parece que você se submete a uma mulher poderosa, mesmo fora da transa! E isso está Ihe fazendo sofrer ("grita comigo, não sabe conversar, quer tudo do jeito dela (...), não desapego nem por reza brava... (...) ela me barra de todo jeito").Percebe?

Suas questões aparecem na sexualidade, mas elas pedem um aprofundamento, no sentido de entender porque você se sente paralisado numa relação que não Ihe dá prazer. Isso vai além do sexo! É impossivel dizer se isso tem a ver com "uma questão com o pai mal resolvida", mas certamente tem a ver com toda sua história! Incluindo suas relações com a família, amigos, a infância, a adolescência, enfim, todas as experiências afetivas (veja que eu não disse sexuais e sim afetivas!) que teve. Você pergunta se ajudaria contar essas coisas todas para uma psicóloga... diríamos que é fundamental! Isso tudo o que você contou faz parte desse repertório afetivo que é material de uma psicoterapia... Sabemos que não é fácil, mas por outro lado, podemos the garantir que nós, psicólogos, estamos habituados a diversas questões humanas, esse é o foco de nosso trabalho! Sabemos que é um material precioso e, por isso, cuidamos muito bem, com sigilo, acolhimento, humanidade. Tudo o que é humano é importante para nós! E nosso objetivo é ajudar as pessoas que nos procuram a viver com menos sofrimento, com mais aceitação e prazer.

Depois dessa orientação, nossa indicação é que você procure um novo psicólogo ou algum dos que já teve para reiniciar uma psicoterapia. Dentro da psicoterapia você poderá encontrar um espaço de acolhimento, onde conseguirá expor suas dificuldades e questões, sem julgamentos. Se quiser alguém novo, sugerimos então que você procure indicação de psicólogos com alguém de sua confiança (médicos, parentes, amigos). Caso não tenha uma indicação ou não possa pagar por um atendimento particular, você pode procurar alguma clínica-escola de uma Faculdade de Psicologia próxima de sua residência. Nessas instituições, você conseguirá ser atendido por valores mais acessiveis ou até mesmo gratuitamente. Se morar nas proximidades de São Paulo, você pode procurar a clínica da PUC-SP no tel.: (11) 3862-6070

\author{
Atenciosamente, \\ NPPI - Núcleo de Pesquisa da Psicologia em Informática
}


Pensei bastante no que vocês escreveram, e ainda restam algumas dúvidas...

Já li em vários lugares essa questão do prazer anal, mas mesmo assim é meio esquisito, né não? E acho que são pouquíssimas as mulheres que topam, daí outro medo meu de terminar esse namoro.

Já fiz terapia, e minha grande questão é esse namoro de quase 7 anos. Fui forçado a ficar noivo, agora sou forçado a casar ano que vem, e mesmo atendendo esses pedidos, nunca está bom pra ela, parece que sempre quer mais, que se eu der a mão, ela quer o braço e assim vai... Ela implica com meu cachorro, meu videogame, fala mal do meu trabalho, quer tudo do jeito dela na hora que ela quer, e o pior, quando eu falo qualquer coisa que ela não gosta, ela grita e briga por horas. É a relação da histérica com o obsessivo.

E o pior, que mesmo tendo feito terapia (comportamental e depois fenomenologiaexistencial) não consego desapegar, deixá-la ir, terminar o namoro... E toda semana ela briga, fala que vai terminar, só pra eu atender seus pedidos, dizer "faz isso não gata, para de brigar, e talz", sempre a mesma coisa. Eu fico chateado, quero terminar, mas na hora não consigo. E a terapia não me ajuda... Tudo bem que não consigo falar tudo, muita coisa eu guardo, mas não sei o que fazer...

Tipo, marquei o casamento mês passado, três dias depois brigamos por qualquer besteira (como sempre), e ela ficou doida, gritou, xingou, falou que ia terminar... onde já se viu isso? Tá falando em casar, e faz uma coisa dessas? E é todo dia... E depois eu fico mais ainda na dúvida se é isso que quero ou não, e ela apela (grita e xinga) por eu dizer que estou na dúvida sobre o casamento... claro que estou! ela me deixa inseguro, se realmente vale a pena! Pois quando ela não está histérica, nossa relação até que é boa, damos risadas, ela não implica com meu cachorro, comigo, com o videogame, meus amigos, nada... Aî vem a histeria (que pode ser algo que alguma amiga dela tenha falado, ou alguma dificuldade que ela teve na faculdade, ou mesmo eu achar ruim com ela por ter feito a inscrição num concurso, e chegar na véspera ela dizer que não vai fazer mais, pois não vai passar... e eu insisto que mesmo sem passar rola como experiência, e ela não aceita de forma alguma eu ter uma opinião diferente... não obrigo ninguém a fazer a prova, mas minha opinião acredito que tenho o direito de expressar), e com essa histeria ela muda de personalidade (literalmente). Ai fica complicado ter certeza de qq coisa...

Cheguei a conclusão de que ainda estou com ela por esses momentos de lucidez, e também por ela ser uma pessoa talvez um pouco mais econômica que as mulheres de amigos meus, que gastam muito, e eles tem de se desdobrar... e eu sou uma pessoa econômica, só compro uma camisa se não tiver opção (por exemplo), almoço em casa ou no restaurante universitário... Só que esse custo-benefício dela tá ficando meio caro, pois não tenho prazer sexual (esse lance dela me penetrar já tem 1 mês ou mais que perdi a vontade), quando estou com ela quase sempre sai brigas, ela não troca ideias como faço com meus amigos e amigas, não tem assunto, e VIVE me cobrando que meu pai poderia me ajudar a construir uma casa e que é um absurdo ele não fazer isso pra ajudar o próprio filho (sendo que eu nem falo com ela que ele vai me ajudar, pois senão ela monta mais ainda em cima de mim). E vou até precisar 
procurar um advogado, pois se eu for casar, quero ver se meu pai construir a casa, e depois fizer uma doação seria uma forma de garantir que numa separação ela não tenha direito a nada.

De qualquer jeito, tenho 34 anos, estou terminando a faculdade, meus amigos já foram quase todos embora, se eu ficar sozinho não sei o que fazer, pra arrumar outra namorada ou mesmo companhia pra sair, e meu maior medo e arrumar uma mulher ainda pior... E isso me consome a uns 4 anos... e nem terapia ajudou...

Vi no site que são no máximo 8 trocar de e-mails... se puderem me dar uma luz pra que a terapia depois possa se encaminhar, fico agradecido!!

Abraços,

4 de setembro de 2013

Olá,

Nós lemos seu primeiro e-mail, assim como também lemos esse! Quando dizemos que você pode confiar nos psicólogos, estamos sendo muito sinceros. Parte de nosso trabalho é cuidar de tudo que nossos clientes confiam a nós, aqui e em nossos consultórios.

Ao ler seu e-mail, percebemos o quanto você atribui a sua atitude de estar com sua namorada como se não fosse uma escolha sua. Você diz "Fui forçado a ficar noivo, agora sou forçado a casar ano que vem". Você não é forçado a nada! Se você está tomando essas decisões é porque existem razões inconscientes que Ihe levam por esse caminho. Ninguém, além de sua própria cabeça, está Ihe mantendo nessa relação e fazendo todos esses planos.

Como dissemos no outro e-mail, ao contrário do que você acha (que está com ela pelos momentos de lucidez e pelas horas mais tranquilas), achamos que sua questão central tem a ver com a submissão. Submissão sexual e submissão "existencial", afetiva. De um jeito muito profundo, sua dificuldade não está ligada a razões concretas e sim, ao desejo e, ao mesmo tempo, repulsa por uma relação de submissão. Percebe o paralelo com a sexualidade?

Por isso que talvez as terapias não estejam Ihe ajudando, você está deixando de expor algo que pode ajudar muito no processo terapêutico. É como se você estivesse fazendo um bolo e dissesse: "vou deixar só de por o açúcar!". E depois achasse ruim que o bolo não está doce!

Não estamos dizendo que seja fácil se abrir, mas nesse caso onde a sua sexualidade (deixarse penetrar, se submeter, etc) tem uma relação muito próxima com suas queixas (não conseguir ir embora, deixar que ela mande em tudo, penetrando em toda a sua vida!), é fundamental que você encontre um profissional ou procure um antigo e construa com ele (ou ela) uma relação mais confiável e aberta.

Você PRECISA trabalhar sua sexualidade, seu modo de se vincular as mulheres e até seus valores - dinheiro, sustento e casamento - ANTES de se casar Veja, é de sua vida que estamos 
falando! Ela é sua e de mais ninguém! Você não pode passar pela vida como se não tivesse tido outra opção... pense nisso e siga as indicações de nossa primeira resposta: você precisa reiniciar sua psicoterapia, se entregar ao processo, se abrir sem medo e, depois, tomar suas decisões.

Em nosso site, está escrito mesmo que fazemos no máximo 8 trocas, mas isso é para um serviço específico, com critérios nos quais seu caso não se encaixa (pessoas que moram fora do país ou em lugares muito ermos, onde não existe serviço de Psicologia). Você tem todas as condições para retomar um atendimento presencial. Além de ter essas condições, nós acreditamos que essa é a melhor orientação para seu caso!

Pense nisso! Esse é um momento importante de sua vida e pode definir todo seu futuro.

\section{3 de setembro de 2013}

Prezados,

Segui a orientação de vocês, e estou fazendo terapia aqui na minha cidade.

Só que não consigo me abrir, falar as coisas que falei com vocês por e-mail. Toda sessão eu vou decido a falar, mas não consigo, igual das outras vezes... isso está me frustrando bastante, pois vejo que não resolve... é muita, mas muita resistência... não sei mesmo o que fazer... falei pra ela que não consigo falar, que queria, e mesmo assim não está adiantando...

Existe alguma orientação nesse sentido?

Obrigado!!

02 de outubro 2013

Olá,

Que bom que você está em terapia! Mesmo com todas as dificuldades, você está no caminho certo.

Muitas vezes a dificuldade em falar vem do medo do julgamento que o outro fará a respeito do assunto. Mas é importante entender que psicólogos são profissionais acostumados a ouvir relatos pessoais diversos e não julgam comportamentos. Dessa forma, você pode tentar alguma das sugestões abaixo como forma de facilitar sua comunicação com sua terapeuta.

A primeira atitude a tomar, é dizer para sua psicóloga de suas dificuldades, mesmo sem contar o assunto. Parece que isso você já fez. Pode pedir a ela ajuda para criarem juntos alternativas para essa dificuldade. 
Outro caminho que você pode seguir é imprimir essa nossa troca de emails e levar em uma sessão, é possivel que ela peça para você ler ou ela lerá, mas vocês poderão falar disso no própria sessão.

Uma outra decisão, mas você precisa ver com ela se é possivel, é enviar a ela essas orientações. Nem todos os psicólogos aceitam esse tipo de contato, pois fica difícil receber um material e não estar junto com o cliente para poder trabalhar, mas pode ser que ela aceite.

Como vê, tem muitas alternativas, mas o mais importante você está fazendo: cuidando de você antes de tomar qualquer decisão importante de sua vida, como casar.

Esperamos ter podido ajuda-lo novamente,

25 de outubro de 2013

Ola!

Enfim, depois de 4 meses apos meu primeiro contato com o nppi, eu consegui seguir sua orientacao e entreguei nossos emails para minha psicologa.

Ja faco terapia com ela ha mais de 2 anos, e nunca tinha tocado naqueles assuntos. Nao toquei, mas enviei os emails.

o que ela me disse: $q$ eh pra eu me perguntar o pq nao consigo deixar minha namorada, se tem a ver com minha bissexualidade...

Fala serio!!! Vcs msm me falaram q $n$ tem nada a ver com homossexualismo, mas sim me envolver com mulheres poderosas...

Achei muita falta de epoche falar isso e encerrar a sessao... fui julgado e sentenciado, sem direito a resposta.

Perdi a confianca nela. Nao fui acolhido.

Ela tb pide nao ter gostado de que eu tenha confiado num terapeuta virtual e nao nela... vai saber.

Queria saber a opiniao de voces. Pois ela nao me tratou como vcs, pois aqui eu me senti acolhido...

Obrigado de novo.

1 de novembro de 2013

Olá,

Que passo importante que você deu! Sabemos que não deve ter sido nada fácil, mas muito bom.

Bom, mesmo não tendo causado o efeito que você esperava, estamos valorizando a sua atitude! Você se abrir, significa mais aceitação... sua e não dos outros.

Pelo que você contou, você enviou as mensagens e vocês só falaram disso ao final da sessão seguinte. Talvez tenha sido pouco tempo e com poucos elementos (os e-mails) para que sua psicóloga 
pudesse ter maior clareza dos seus conflitos, de seus desejos, dos seus medos, enfim, de todas as dinâmicas envolvidas. Ela pode ter se precipitado, mas nós, psicólogos, somos humanos! Podemos errar, exagerar, faltar, acolher demais, de menos... É na relação que vamos nos acertando, como na vida. Sem idealizações, sem perfeições.

Nossa dica é que você diga a ela como se sentiu. Estamos acostumados com essas conversas difíceis com nossos clientes. Diga que acha que ela se precipitou, que não é isso que você sente (desejo por homens) e que não se sentiu acolhido... Falar disso depois de falar de suas questões mais profundas será bem mais fácil.

Se você, ainda assim, não sentir que pode confiar nela de novo e se sentir acolhido de novo, ai pode pensar em procurar outra pessoa... mas lembre-se que isso implica em se abrir novamente, o que deve ser mais fácil numa segunda vez lou melhor, terceira, já que conosco você se abriu também), mas mais trabalhoso.

Independente da resposta dela, você fez o que é melhor para você. Dessa vez, você não ficou submetido, você foi ousado, corajoso e, apesar de todo o medo e vergonha, fez o que era importante para você e não para o outro. Parabéns!

Atenciosamente,

\subsection{A análise dos e-mails recebidos}

Frente aos e-mails recebidos, faço uma análise ponto a ponto a fim de melhor compreender as possibilidades clínicas. Através dessa análise, levanto também algumas questões relativas as particularidades do atendimento online.

04 de agosto de 2013

\section{Olá!}

Gostaria de receber a orientação online.

Há mais ou menos 1 ano e meio conheci o serviço oferecido por vocês através de um amigo que realizou um projeto de pesquisa sobre esse tema. Desde essa época penso quase todos os dias em lhes enviar um e-mail. Por mais simples que pensei que fosse de escrever, por se tratar de um contato virtual, não está sendo tão fácil assim. Mas agora estou decidido a ir em frente.

O que acontece comigo é o seguinte: já fiz terapia por diversos anos (contando tudo uns 11 anos, nas abordagens comportamental, transpessoal, rogeriana $e$ fenomenologia), e tem coisas que nunca consegui conversar pessoalmente, por medo 
de ser julgado (o que ela vai pensar de mim), ou por não conseguir mesmo, eu vou na terapia pensando assim - dessa vez vou falar - mas nunca sai e estou na mesma há muito tempo.

$\mathrm{Na}$ abertura da mensagem, ele parece buscar prender a atenção daquele que lê, como se usasse suas palavras para mostrar o quão difícil tem sido o seu viver e quisesse, de alguma forma, cativar o leitor. Fala do tempo necessário para recorrer ao serviço, como se estivesse reunindo forças para lidar com algo tão grande e que o assola há tempos, mas que foi sendo adiado por ser temido. Assim, já tendo recorrido a um modo de fala presencial, opta por escrever: imaginando ser mais fácil escrever do que falar face a face com alguém resolve enviar um e-mail. Contudo, ao escrever deu-se conta que esse processo também the seria custoso.

Será que o fato de não estar frente a frente com o outro se torna um grande facilitador? Pela minha experiência com outros relatos recebidos no serviço, é como se o olhar do outro pudesse julgar, e o fato de se estar em contato com uma tela em branco e com a possibilidade de escrever sob qualquer apelido e e-mail, encorajasse alguns a buscar ajuda para algo que supostamente não teriam coragem presencialmente. Nesse sentido, para compreender Marcelo $^{9}$ me parece possível apenas se, ao mesmo tempo, também recorro a toda minha experiência nesses anos com esse tipo de atendimento.

Nesta mensagem, posso então compreender que, ao se deparar com a necessidade de contar sua história de forma sucinta e escrita, é como se fosse necessária outra organização, diferente da fala direta, ou seja, uma priorização de temas e assuntos que serão abordados afim de trazer luz ao terapeuta a respeito do "seu caso". Na minha experiência no NPPI encontrei e-mail nos quais, a escolha de um tema parece ser meticulosa, enquanto para outros, simplesmente surgem palavras que são escritas sem ordem alguma, como que jogadas na tela. Para Marcelo em particular, tocar em algo tão íntimo e secreto pede tempo e reflexão. $\mathrm{Na}$ verdade, a coragem parece demorar a aparecer-lhe apesar de sua expressa vontade em compartilhar: diz ter sabido do serviço há um ano, pensando frequentemente em escrever. Qual seria o sentido de ter se decidido por escrever nesse momento: seria para se aliviar? Seria para expor algo muito sofrido e que pede saída? Seria apresentar-se por algo reprovável em si mesmo? Com tanto cuidado, imagino que no mínimo é algo que socialmente ele considera não aceito e sente que precisa se proteger de comentários julgadores. Afinal, como dito por ele, "o que ela vai pensar de mim..." Estaria ele buscando um olhar que o aceitasse por se perceber inaceitável para si mesmo?

\footnotetext{
${ }^{9}$ Nome fictício do interlocutor, uma vez que ele nem assinou a mensagem.
} 
Por outro lado, e ao mesmo tempo, questiono se esta forma de se apresentar, onde ele dá voltas e cria um suspense acerca de si mesmo, não estaria implicando prender a atenção do leitor, como que pedindo um cuidado maior com aquilo que será dito a seguir. Afinal, deixa claro já ter passado por diversos processos terapêuticos nos quais não conseguiu se expressar. Teria dificuldade em confiar no outro? Ou seria ele prisioneiro de algo, de um grande segredo? Ou ainda, novamente, seria esse um jeito de tentar "comprar" aquele que lê, como um pedido de atenção especial?

Namoro há 6 anos, tem 6 anos que quero terminar, ficar solteiro de novo (tenho 34 anos agora), mas tenho de medo de arrumar uma namorada pior que a atual (que é meio infantil, grita comigo, não sabe conversar, quer tudo do jeito dela, etc), e nem isso consigo resolver, não desapego nem por reza brava...

Apresenta-se por sua dificuldade de relacionamento amoroso. Contudo, ao se referir à dificuldade de entrega em suas terapias anteriores, não estaria já ele falando de questões relacionais? Mas pela construção do e-mail, fico com a impressão que os parágrafos anteriores foram apenas um preâmbulo para o que irá começar a narrar. Enfim, assim como não consegue falar e se posicionar na terapia, pelo visto faz o mesmo em seu relacionamento amoroso. Namora, mantém-se nessa relação, mas não consegue vivê-la de forma plena. Reclama do comportamento da namorada, como se não tivesse escolha, como se fosse obrigado a ficar com ela. Quais seriam os motivos reais que o fariam a ficar com ela? Ele diz querer terminar com a namorada mas ao mesmo tempo relata uma duração de anos nessa relação.

Caberia nesse ponto um questionamento a respeito dos limites da orientação online como propostos pelo serviço do NPPI, e que foram construídos visando atender ao que se compreende como norma do Conselho Federal. Fazer perguntas de forma em geral amplia o número de trocas, uma vez que o outro se sente mobilizado a responder. Assim, o limite estabelecido de trocas possivelmente seria ultrapassado.

Diante do que ele apresentou com relação ao namoro, surgiu-me a possibilidade de perguntar, se estando com ela por 6 anos em situação tão desagradável, não teria havido nada de construtivo nesse relacionamento? Mas, procede perguntar o que desejamos neste tipo de atendimento, mas que talvez fosse pertinente em um atendimento presencial? Afinal, perguntas que buscam esclarecimento e reflexão podem levar as pessoas a responderem em novo e-mail. Isto implicaria quebrar a proposta inicial da orientação, que se limita ao menor número possível de mensagens, se possível apenas uma. É preciso, assim, pensar em como construir ou mesmo se cabe tocar nesse ponto uma vez que se perguntado fará com que 
apareça uma resposta ou uma nova mensagem, o que sairia do padrão proposta para respostas pelo serviço. Seria muito importante saber disso, ou mesmo questioná-lo a respeito de suas relações?

Mas voltando ao ponto, também sou vicidado em assistir vídeos de sexo pela internet, e atualmente estou assexuado em relação a minha namorada, não quero nem chegar perto, e quando transo sem camisinha, me dá uma coceira no pênis (tá aversivo a coisa), não gosto do cheiro dela, tá tenso!!! E na internet é aquela bizarrice... o ângulo da câmera tem de ser perfeito, com a vagina perfeita, posição que me agrade, senão nem assisto... até a tonalidade de pele da mulher interfere... E pra piorar (aí que não dá pra conversar com minhas psicólogas) é que tive uma fixação por strapon (aqueles pênis de borracha que a mulher usa), e fiquei assistindo várias vezes esse tipo de video... até que não sei como minha namorada topou usar isso, no início eu gostava dela me comer, mas até isso hoje não me satisfaz (com ela), eu fantasio transando com outras mulheres dos vídeos. Pra piorar mais ainda, começei a ver vídeos com shemales (travestis), e volta a questão acima, tem de ser uma travesti perfeita, a cena perfeita, senão não dá... e só gosto de ver a travesti comendo o homem (que não pode ser afeminado, senão também não gosto).

Começa agora a falar de sexualidade. E toca na questão de não se abrir com a psicóloga. Seria esse então o ponto principal? Mistura o relacionamento com o desejo sexual de ser penetrado e seu gosto por vídeos de sexo na internet. Parece-me que o relacionamento apresenta questões que precisam ser resolvidas, e como não o são, está perdendo o desejo pela namorada, encontrando assim um grande refúgio na variedade da internet. Os vídeos da internet são campo vasto de opções, com possibilidades de se selecionar exatamente aquilo que se gosta, é um jeito interessante de lidar com seu desejo sem realizá-lo, mas também sem reprimi-lo. A questão que fica é a possibilidade de estar vivendo mais a fantasia do sexo do que a realização dele, o que parece estar incômodo. Contudo, de alguma forma parece ter alguma abertura com essa namorada, pois, afinal, conversa com ela sobre algo tido como socialmente delicado: a questão do strapon.

O tempo todo busca arrumar argumentos e justificativas que digam que ele não quer mais estar com ela, como se tentasse, através da escrita, convencer a si mesmo do seu "não querer estar". Embora, ao mesmo tempo, fala que não consegue se desapegar.

Envergonha-se de suas práticas sexuais, falando que isso é um ponto que realmente não teria coragem de contar às terapeutas. Quantas terapeutas teriam sido? Como seria essa relação que estabelece com elas? Caberia perguntar isso em uma orientação por e-mail? Ajudaria na compreensão da situação por parte dele? 
Neste ponto, questiono qual o sentido e diferença de uma orientação e terapia, qual a fronteira de perguntas que pode existir entre as duas? O que pode ou não ser abordado em uma mensagem? Seria apenas porque perguntar demais pede respostas, e respostas levam a muitas trocas, questão essa não permitida nesse tipo de atendimento. No serviço, a tentativa de manter a procura sob controle estabelece um número de trocas bem limitado, preferencialmente no limiar mais baixo possível. Embora haja possibilidade de ter atualmente até 20 trocas, tentamos ficar entre 1 e 3 mensagens. Na época do recebimento desse e-mail, falávamos em possibilidade de até 10 trocas. Nesse sentido, qual a relevância de tal pergunta? Sinto aqui uma diferença entre o presencial e o virtual: a liberdade do presencial de caminhar por onde se sente ser preciso, de questionar aquilo que parece ser uma possível "pista" , ou um novo atalho para algo. No virtual, na forma atual, é preciso um certo foco, uma préseleção de dados, como se fosse um resumo de um atendimento, uma maneira enxuta de olhar e questionar.

Ai li na internet algo um dia que falava resumidamente assim: se o homem tem tesão nessa questão do pênis, e tem de ser tudo perfeito e talz, sem contato intimo, não tem nada a ver com homossexualidade (antes eu tinha medo de ser gay, mas tentei assistir alguns videos pra tirar a dúvida, e não senti tesão nenhum, nem nojo, só não achei graça), e sim com uma questão com o pai mal resolvida... aí explicava um pouco mais, e depois de ler isso, fiquei um mês sem querer usar o tal do brinquedinho... aí hoje de vez em quando usamos, mas a questão tá mudando de figura, hoje tô vendo que não tenho tesão nenhum na minha namorada, que só fala em casar, 24 horas por dia, me pressionado, falando que termina se não casar, e tá muito foda, tô vivendo um estresse muito grande, pois tenho medo de terminar e começar tudo de novo, já namorei outra vez antes por 6 anos, ela me traiu, terminamos, fiquei muito mal, depois melhorei, fiquei com poucas garotas, e comecei a namorar com essa...

Parece querer uma explicação para seu desejo, como se precisasse entender aquilo que julga ser fora do padrão. Se sentindo de alguma maneira protegido nesse espaço, vai à internet, mesmo tendo essa questão muito viva para si. Encontra uma fala que diz ser o interesse masculino em pênis, aponta a possibilidade de uma questão com o pai e isso faz com que restrinja o uso do objeto "brinquedinho" por algum tempo. O que será que aconteceu? Por que depois de ler isso fica 1 mês sem usar? Medo dessa associação com o pai? Fez sentido para ele? Como é esse relacionamento com o pai? De novo me esbarro na questão da internet. Presencialmente abriria essa possibilidade de questionamento. Mas virtualmente, 
devo fazê-lo? Essa provavelmente seria uma ramificação do que tem contado, abrindo um novo campo a ser explorado.

Chama-me a atenção também, muito provavelmente pela possibilidade da leitura detalhada do relato, o que diz "se o homem tem tesão nessa questão do pênis, e tem de ser tudo perfeito e talz, sem contato intimo, não tem nada a ver com homossexualidade." Nesta colocação fala de um não contato íntimo. Seria assim o relacionamento com a namorada? Apesar de juntos, sem contato íntimo no sentido de ligação entre eles?

Junto a essa questão da sexualidade fala de casamento, da pressão da namorada, de querer terminar e não conseguir por medo. Medo de ficar só? Ele diz que é de começar tudo de novo, mas então engata em uma história que fala de uma namorada de 6 anos que o traiu, o que o fez sofrer com isso. Seria o medo da intimidade a qual se referiu acima? Será que esse relacionamento anterior teria deixado algo que não foi superado?

Dai o que penso sempre é que tive poucas garotas na minha vida, e que as poucas que tive era bom demais no início (na questão sexual), aquela descoberta, tirar a roupa, sentir o corpo... e hoje não tenho mais isso... (tive isso os 6 anos que namorei com a outra, que me traiu, nela sentia um tesão incrivel)...

Poderíamos pensar na questão inicial da atração que passa com o tempo, mas então ele fala que com a ex-namorada isso se manteve nos 6 anos que estiveram juntos. Seria então uma questão afetiva? De novo lança o foco de atenção sobre a ex, sobre a traição. Valeria perguntar sobre isso? Meu interesse a respeito de seu relacionamento anterior cresce uma vez ele menciona já ter tido outro relacionamento por quem o desejo se mantivera, mas caberia na orientação? Ou isso teria de ficar para terapia presencial? Seguindo os padrões atuais do serviço, isso teria de ser assunto para terapia, embora fosse possível se comentar com ele a questão, abrindo a possibilidade de olhar para isso e pensar a respeito do assunto.

Mudando de assunto, quando eu tinha 16 ou 17 anos, tinha saído do colégio e estava estudando pro vestibular, não sabia o que fazer da vida, tinha um amigo de uma menina que eu era apaixonado, e fiquei apaixonado uns 6 anos, minha amiga até hoje... Só que esse amigo dela era gay, e resumindo, um dia voltando de uma festa, trêbado, e depois de fumar maconha, meio que transamos (se pode-se dizer isso)... eu deixei ele me comer num beco... e doeu demais da conta, ficou doendo uns 15 dias... Eu fiquei mal demais, ele ficou me ligando, eu fugi e nunca mais aconteceu nada... Só que durante muito tempo eu fiquei com medo de ter me tornado gay pq tive um fato desses... até que deixei pra lá. 
Quando ele toca no assunto sentimento, ele mesmo muda de assunto e volta para sexualidade. Seria ela uma fuga? Isto porque a questão da homossexualidade volta o tempo inteiro por conta do interesse em ser penetrado. Chama-me a atenção ele mencionar que era um amigo da menina da qual ele gostava. Ter relação com esse moço dificultaria uma aproximação com a menina? Também parece que o fato de estar drogado faz com que ele libere suas fantasias de forma mais fluida, sem tanta preocupação. Será que ele teria medo de se assumir homossexual? Ou bissexual? Qual seria o problema para ele dessa escolha?

Só que nem esse tipo de coisa jamais consegui contar pra psicóloga alguma (tive várias)... e minha dúvida é: se eu contasse ajudaria alguma coisa no meu caso? Pois eu faço terapia até hoje e não consigo resolver minha vida, terminar o namoro que (apesar de ter seus pontos bons, digo com isso: estou na minha zona de conforto), mas tem muitas coisas que não são boas, não gosto de brigas, de não ter amigos, pois ela me barra de todo jeito, eu acabo só ficando em casa, no videogame ou internet, e sinto muita falta de amizades... Só que de outro lado, com 34 anos, como vou fazer amigos? o pessoal do meu trabalho são meus amigos, mas são todos casados... não tenho ninguém aqui pra sair na balada, vou acabar ficando mais frustrado ainda, ter de ir no fundo de carreira que são os puteiros dessa cidade... Fico TODO DIA NESSE DILEMA...

Ele questiona se ajudaria em algo falar isso para a terapeuta. Mas parece desesperado para contar para alguém, tanto que diz ter pensando em escrever para o serviço durante um ano. Parece que está tão complicado lidar com esses sentimentos que ele prefere esconder e se manter no lugar em que está. Mas aqui me parece que quem escreve é como se fosse uma criança, um menino que não quer crescer e assumir responsabilidades sobre sua vida e que, ao ser pressionado, está buscando um jeito de perpetuar esse mesmo movimento de não crescer. Vê-se sem amigos, diferente dos colegas de trabalho justamente por não ser casado. Então pensa em se encaixar no padrão ao invés de tentar buscar outra pessoa, porque acredita que não encontraria outra namorada. Seria isso que o faz manter-se nessa relação? Por outro lado, diz que eles têm bons momentos, depois de dizer em vários outros momentos que não a aguenta mais. Seria medo de construir um futuro adulto? Será que é a questão da sexualidade que o atrapalha? Será que são seus relacionamentos que estão confusos por uma dificuldade de entrega? Será que ele prefere não escolher um caminho para não se sentir responsável por isso? Será que ele se conhece minimamente e sabe quais seriam realmente seus desejos?

Nesse mesmo tema, antes disso acima acontecer, eu já tinha essa fixação anal, e como era adolescente, o que fazia era pegar uma cenoura, camisinha e enfiar lá... só que um belo dia, eu joguei isso no lixo de casa (na verdade um lixo grande de fora da 
minha casa), dentro de um saco preto, e minha mãe enxerida abriu isso e veio me perguntar o que era... Cara, eu já era estressado e brigava muito com minha mãe por ela invadir meu espaço, isso ai é uma coisa que me deixou muito sem graça... só pra constar..

Desde a adolescência a sexualidade vem despertando curiosidade, trazendo experimentações, tidas e vividas como não convencionais. A mãe invade o que ele chama de seu espaço, ele se sente constrangido, como com o rapaz com quem fez sexo e fugiu. Tem curiosidade, mas parece temer assumir uma escolha? Qual o sentido de trazer essa frase “... só pra constar..."? Seria para justificar ou realmente marcar um interesse por ser penetrado desde a adolescência? Como ficou para ele esse episódio com a mãe? Ou será que estaria buscando uma aceitação daquele que o atende por e-mail?

E na minha primeira transa, em Porto Seguro, viagem do terceiro ano, que perdi a virgindade com uma mulata, numa pousada... foi tenso, porque ela colocou a camisinha com força, ai doeu, broxei e fiz sem camisinha mesmo depois, só que pra piorar ela falou que meu pênis era pequeno (muito tempo fiquei bolado com isso), ele tem uns $13 \mathrm{~cm}$ (depois que emagreci), e não sei se é um número bom ou não, mas hoje acho que sim... estou tranquilo quanto à isso, agora minha dúvida é em relação à grossura...

Parece que, de alguma forma, ele quer mostrar que a sexualidade como um todo está confusa: se não é a questão de ser penetrado é a questão do tamanho e agora da grossura. É como se buscasse certezas de que seus desejos são normais, assim como seu corpo. Seria difícil se aceitar? Será que permanece com essa namorada por ela tolerar todas essas coisas tão conflitantes para ele (tamanho, grossura, gostos diferentes, strapon)? Afinal ele aponta no e-mail a questão de permanecer com ela como sendo um problema, o que me faz pensar em que razões o levam a isso.

Tá vendo, eu nunca na minha vida ia conseguir falar isso presencialmente, nem por skype...

Aqui parece justificar o porquê de sua escolha em pedir um auxílio via e-mail. Teria vergonha de assumir quem é frente ao outro visualmente, e, assim, por escrito lhe pareceria mais fácil? Não ver o outro parece ajudá-lo a liberar suas dúvidas e confusão: diante a uma tela em branco se permitiria liberar a fantasia, podendo falar de qualquer coisa sem sentir que o outro estivesse interpretando ou julgando aquilo que fala. Neste caso, parece que o fato de ser por escrito se mostra como um caminho intermediário possível: um jeito pelo qual ele pode experimentar, ou seja, experimentar o outro assim como vem experimentando sua 
relação com sua sexualidade, sem se assumir totalmente? Ou seria apenas um caminho facilitador para uma maior abertura de si mesmo para si mesmo?

Recebemos muitas mensagens com questões que tangenciam a sexualidade, assim como muitas que mencionam o anonimato como grande facilitador na hora se de expor, neste exemplo ambos fatores se encontram. É frequente em mensagens que seja citado o fato de não se ter o olhar do outro, de se sentir socialmente protegido uma vez que mesmo que o terapeuta lhe encontre na rua não saberá quem você é; a escrita em um momento de crise expressa a vontade de falar maior do que a vergonha, enfim, o anonimato.

Espero que eu consiga uma luz com vocês...

Exatamente sobre o que ele quer ajuda? Sobre a namorada? Sobre a sexualidade? Sobre suas escolhas? Sobre seus pais? Fica um pouco vaga qual é a questão central, o "por que procurou"? Qual de fato seria sua demanda? Como construir uma resposta que abranja tantos pontos diferentes sem, ao mesmo tempo, indagar e questionar muito? Porque, seguindo as normas do conselho, não posso em uma orientação aplicar muito o foco. Mas por que não? Qual seria o problema de questionar e ampliar o próprio questionamento dele? Como mobilizá-lo para efetivamente fazer algo por si mesmo de forma breve e sem me estender?

Ele não assina a mensagem. Ele não se nomeia em tempo algum. Seria essa também uma forma de não se assumir frente a sua própria história?

Enfim, indagações, questões, interrogações, tentativa de compreensão. E como continuar encaminhando a questão de como faço o que faço?

24 de agosto de 2013

Olá pessoal!

Muito obrigado pela resposta, pensei que talvez vocês não fossem ler...

Pensei bastante no que vocês escreveram, e ainda restam algumas dúvidas...

Nesta segunda mensagem, ele começa em um tom diferente da primeira, referindo-se à equipe como "pessoal". Diria de uma sensação de mais proximidade ou de indeterminação por ainda não pertencer a lugar algum? Estaria esperando uma plateia para o que vai narrar a seguir? Apesar de a resposta ter sido enviada a ele como equipe, comumente as pessoas se dirigem nos e-mails como que a um único profissional, o que faz refletir se a assinatura como “equipe" assinalou a possibilidade de estar sendo lido por "muitos outros".

Ele agradece a escuta, reforçando que não esperava receber atenção. Seria essa uma impressão que ele tem de sua vida? De não ser escutado? De não ter seus sentimentos validados pelos outros? Ou ainda uma forma de fazer o redator se sentir valorizado frente a seu agradecimento? 
Ao dizer ter pensado bastante sobre o que lhe foi escrito, estaria expressando a valorização do trabalho de quem está do outro lado? Ou seria um modo de solicitar nova escuta? Será que por ter se sentido ouvido, ele resolveria abrir um pouco mais questões que estavam veladas até então? Afinal, sendo um serviço de orientação como compreender e como é compreendida nossa disponibilidade?

Já li em vários lugares essa questão do prazer anal, mas mesmo assim é meio esquisito, né não? E acho que são pouquíssimas as mulheres que topam, dai outro medo meu de terminar esse namoro.

Já fiz terapia, e minha grande questão é esse namoro de quase 7 anos. Fui forçado a ficar noivo, agora sou forçado a casar ano que vem, e mesmo atendendo esses pedidos, nunca está bom pra ela, parece que sempre quer mais, que se eu der a mão, ela quer o braço e assim vai... Ela implica com meu cachorro, meu videogame, fala mal do meu trabalho, quer tudo do jeito dela na hora que ela quer, e o pior, quando eu falo qualquer coisa que ela não gosta, ela grita e briga por horas. É a relação da histérica com o obsessivo.

Assim como na primeira mensagem, apresenta novamente a questão da sexualidade, porém agora com certa estranheza acerca de suas preferências sexuais, além de por esse modo justificar-se por permanecer no seu atual relacionamento: ao mesmo tempo busca desculpas para sua história e não consegue encobrir seus desejos. A questão do prazer anal é percebida como importante para ele, motivo pelo qual temeria terminar esse relacionamento e não encontrar outra mulher que concordasse em realizar suas vontades. Tal medo diria respeito exclusivamente ao interesse sexual ou haveria questões afetivas que o ligam à parceira? Afinal, sendo o relacionamento de longa data, como expressa se sentir "forçado" a ficar noivo e casar? O que o força? Quem o força? Quais expectativas poderiam estar aí implicadas: papel social, cumprir regras, mas podendo satisfazer seus desejos?

Traz ainda uma fala de não aceitação nessa relação, de se sentir criticado o tempo todo pela namorada, como ela não o aceita e a suas coisas pessoais também não. Seria uma desresponsabilização de sua parte nas discussões? Coloca sempre como sendo ela a causadora, como se ele não tivesse implicação ou participação nisso. Estariam ambos insatisfeitos?

Pelo que ele conta, ela reclama de tudo que toma a atenção dele sem ser ela. Será que ele efetivamente dá atenção a ela? Haveria intimidade com ela? Ou são distantes? Será que essa dificuldade de intimidade seria uma razão de buscar um atendimento virtual? Afinal, diz fazer terapia há muito tempo, porém não tem coragem de falar sobre suas questões mais 
íntimas. Seria uma dificuldade em criar cumplicidade com alguém?

Quando ele fala da relação de ambos, denomina como a histérica e o obsessivo. Quais os estereótipos que criou para ambos com tal rotulação? A partir de onde se denomina como obsessivo?

De novo esbarro no limite de ser uma orientação. Gostaria de compreender muitas dessas questões, podendo ampliar tanto o meu olhar quanto o dele em relação a isso tudo. Mas penso não ser possível nos moldes atuais permitidos.

E o pior, que mesmo tendo feito terapia (comportamental e depois fenomenologia-existencial) não consego desapegar, deixá-la ir, terminar o namoro... $E$ toda semana ela briga, fala que vai terminar, só pra eu atender seus pedidos, dizer "faz isso não gata, para de brigar, e talz", sempre a mesma coisa. Eu fico chateado, quero terminar, mas na hora não consigo. E a terapia não me ajuda... Tudo bem que não consigo falar tudo, muita coisa eu guardo, mas não sei o que fazer...

Tipo, marquei o casamento mês passado, três dias depois brigamos por qualquer besteira (como sempre), e ela ficou doida, gritou, xingou, falou que ia terminar... onde já se viu isso? Tá falando em casar, e faz uma coisa dessas? E é todo dia... E depois eu fico mais ainda na dúvida se é isso que quero ou não, e ela apela (grita e xinga) por eu dizer que estou na dúvida sobre o casamento... claro que estou! ela me deixa inseguro, se realmente vale a pena! Pois quando ela não está histérica, nossa relação até que é boa, damos risadas, ela não implica com meu cachorro, comigo, com o videogame, meus amigos, nada... Ai vem a histeria (que pode ser algo que alguma amiga dela tenha falado, ou alguma dificuldade que ela teve na faculdade, ou mesmo eu achar ruim com ela por ter feito a inscrição num concurso, $e$ chegar na véspera ela dizer que não vai fazer mais, pois não vai passar... e eu insisto que mesmo sem passar rola como experiência, e ela não aceita de forma alguma eu ter uma opinião diferente... não obrigo ninguém a fazer a prova, mas minha opinião acredito que tenho o direito de expressar), e com essa histeria ela muda de personalidade (literalmente). Ai fica complicado ter certeza de qq coisa...

Retoma o fato de já ter feito terapia, assinalando as "linhas" em que foi atendido. Qual o sentido disso? Empenha-se, porém não se resolve? Ou seriam as terapias que não tem funcionado? Estaria de novo esperando que a terapia resolva suas dificuldades? Do mesmo modo, diz não conseguir desapegar-se da namorada, mesmo se sentindo insatisfeito, mas cede às vontades dela. Como é esse modo de se manter em algo apesar de não se sentir bem?

É como se ele não pudesse ser ele mesmo, nem com a namorada nem com a terapeuta. Por não se sentir pronto e nem apto para expor-se, posterga decisões, como se pudesse se 
eximir delas.

O modo como se refere a certas situações de sua vida, como a expressão "Tipo, marquei o casamento mês passado", revelaria um descompromisso em relação a si mesmo? Ou seria um modo informal de se apresentar, como fez com a expressão "Olá pessoal"? Valeria pontuar isso para ele? Seriam as brigas o motivo da dúvida, embora antes havia expressado a questão sexual?

Ao falar do relacionamento, diz "nossa relação até que é boa". "Até que é boa"? Afinal, quem é e onde se encontra na sua própria vida?

Cheguei a conclusão de que ainda estou com ela por esses momentos de lucidez, e também por ela ser uma pessoa talvez um pouco mais econômica que as mulheres de amigos meus, que gastam muito, e eles tem de se desdobrar... e eu sou uma pessoa econômica, só compro uma camisa se não tiver opção (por exemplo), almoço em casa ou no restaurante universitário... Só que esse custo-benefício dela tá ficando meio caro, pois não tenho prazer sexual (esse lance dela me penetrar já tem 1 mês ou mais que perdi a vontade), quando estou com ela quase sempre sai brigas, ela não troca ideias como faço com meus amigos e amigas, não tem assunto, e VIVE me cobrando que meu pai poderia me ajudar a construir uma casa e que é um absurdo ele não fazer isso pra ajudar o próprio filho (sendo que eu nem falo com ela que ele vai me ajudar, pois senão ela monta mais ainda em cima de mim). E vou até precisar procurar um advogado, pois se eu for casar, quero ver se meu pai construir a casa, e depois fizer uma doação seria uma forma de garantir que numa separação ela não tenha direito a nada...

De qualquer jeito, tenho 34 anos, estou terminando a faculdade, meus amigos já foram quase todos embora, se eu ficar sozinho não sei o que fazer, pra arrumar outra namorada ou mesmo companhia pra sair, e meu maior medo e arrumar uma mulher ainda pior... E isso me consome a uns 4 anos... e nem terapia ajudou...

Vi no site que são no máximo 8 trocar de e-mails... se puderem me dar uma luz pra que a terapia depois possa se encaminhar, fico agradecido!!

Abraços,

Ao contar um pouco sobre seu jeito de ser, traz sua idade, a faculdade, a dificuldade em ter amigos. Como é ter 34 anos, pensar em almoçar no restaurante universitário, querer ficar no videogame e se questionar a respeito dos amigos, mas ao mesmo tempo falar em casar? É como se houvesse um descompasso entre os seus próprios projetos de vida. Como ele compreende a si mesmo com tais proposições de vida?

Referindo-se ao medo de estar só e de não se sentir ajudado pela terapia, em que 
medida reflete se si percebe disposto a repensar seu modo de ser e encontrar outras possibilidades para si? Dispõe-se a assumiria as rédeas de sua existência ou manter-se "sustentado" e "guiado" pelo mundo e pelos outros?

Sua própria dificuldade para sair de si expressasse nos modos como se encontra em várias situações: com a namorada e na terapia. Esperaria movimentar-se por esse contato online? Como? Afinal, ao referir-se à quantidade de trocas possíveis para situação de "vício", espera prolongar este contato como mais uma postergação para encontrar-se, cabendo aos "de fora de si" conduzi-lo?

\section{3 de setembro de 2013}

Prezados,

Segui a orientação de vocês, e estou fazendo terapia aqui na minha cidade.

Só que não consigo me abrir, falar as coisas que falei com vocês por e-mail. Toda sessão eu vou decido a falar, mas não consigo, igual das outras vezes... isso está me frustrando bastante, pois vejo que não resolve... é muita, mas muita resistência... não sei mesmo o que fazer... falei pra ela que não consigo falar, que queria, e mesmo assim não está adiantando...

\section{Existe alguma orientação nesse sentido?}

\section{Obrigado!!}

Da informalidade do "Olá Pessoal!" do e-mail anterior e aos "Prezados". Seria limites terem sido apresentados que se expressa distante? Em que medida assumir-se e responsabilizar-se não se fazem possibilidades para ele? Afinal, como vagueia por sua vida sem reconhecer-se: já faz terapia ou iniciou agora pela orientação sugerida online? Mesmo movimento na direção da sugestão de outros?

Referindo-se à dificuldade de apresentar dúvidas em relação a si mesmo diante da presença concreta de outros, expressa angústia por não poder expor-se. Seria o virtual uma possibilidade menos angustiante? Ou estaria ensaiando como expressar-se? Será que poderia se beneficiar se essa forma de atendimento não fosse tão restritiva? Como ser terapêutico diante desse cliente? A transposição do virtual para o presencial poderia ser facilitada? Como poderia abrir-se a outras possibilidade após o virtual? Arriscar-se-ia presencialmente?

Estaria ele experimentando, desde o primeiro e-mail, como apresentar-se por suas questões? Ou estaria ainda no processo de delegar para o outro a responsabilidade sobre suas ações? De qualquer forma, já podia expressar querer e precisar dizer de si à terapeuta. Estaria buscando encontrar um modo para encontrar-se com um acontecimento? Seria pertinente estender a orientação a alguém angustiado e preso? 
25 de outubro de 2013

Ola!

Enfim, depois de 4 meses apos meu primeiro contato com o nppi, eu consegui seguir sua orientacao e entreguei nossos emails para minha psicologa.

Ja faco terapia com ela ha mais de 2 anos, e nunca tinha tocado naqueles assuntos. Nao toquei, mas enviei os emails.

O "Olá" abre uma forma mais espontânea. Apresenta-se como "bom menino" que cumpriu as orientações? Ou realmente busca revelar uma abertura de possibilidade para si mesmo? Sentiu-se escutado e acompanhado em seus ensaios ou encontrou um modo de conduzir-se?

A confusão quanto ao tempo em que está em terapia revelaria sua dificuldade com o tempo real em seu existir? De qualquer forma, a lagarta está saindo do casulo de seus segredos. Seria então esta forma de comunicação um mediador possível em alguns casos? Ou o virtual ainda lhe é protetivo ao dizer não ter falado diretamente de si à terapeuta, tendo, contudo, enviado os e-mails? Ainda uma tentativa de proteger-se do olhar do outro para si? Ou precisa ainda descobrir-se para abrir-se?

O que ela me disse: q eh pra eu me perguntar o pq nao consigo deixar minha namorada, se tem a ver com minha bissexualidade...

Fala serio!!! Vcs msm me falaram $q$ n tem nada a ver com homossexualismo, mas sim me envolver com mulheres poderosas...

Achei muita falta de epoche falar isso e encerrar a sessao... fui julgado $e$ sentenciado, sem direito a resposta.

Perdi a confianca nela. Nao fui acolhido.

Ela tb pide nao ter gostado de que eu tenha confiado num terapeuta virtual $e$ nao nela... vai saber.

Queria saber a opiniao de voces. Pois ela nao me tratou como vcs, pois aqui eu me senti acolhido...

Obrigado de novo.

Nessa comunicação, ele mudou a forma de escrever, apresentando-se mais informal ao recorrer à grafia de internet. Estaria precisando expressar mais diretamente como se sente? Como compreender a mudança na grafia: irritação, desabafo, pressa? Geralmente e-mails, escritos em momentos de muita raiva, ou quando há necessidade de "despejar" algo, possuem esse formato. Afinal, sentiu-se "julgado e sentenciado" pela terapeuta ao dar-se a ver, contrapondo o modo de acolhimento online. Como foi difícil ensaiar expor-se e não sentir-se compreendido em sua angústia. Ou doeu muito ver-se ao ouvir-se por outro? Como não lhe 
foi possível contrapor-se ao que ouviu dizerem de si? Seria menos ameaçador escolher as impressões de si mesmo quando na virtualidade?

Ancora-se na falta de confiança em relação à terapeuta depois do ocorrido como forma de não enfrentar suas próprias dúvidas? Afinal, não é como sempre se apresenta no mundo: não assumindo escolhas? Em que medida expressaria seu descontentamento com a atitude dela? Virtualmente não há como contrapor-se, uma vez que os encontros serão encerrados dada a limitação regulamentar para esse atendimento. Como saber se não estaria mais uma vez culpando a outrem sem encarar sua dificuldade para posicionar-se?

Pedindo a opinião do interlocutor estaria novamente recorrendo ao outro para dirigirse? Seria essa a destinação da orientação? Ou estaria apenas buscando apoio onde sentiu que pode ser ouvido, como modo de validação de seus sentimentos?

Enfim, questionamentos a serem encaminhados... 


\section{O que se desvelou a partir do que se mostrou em todo o texto: questionamentos e algumas considerações}

\subsection{Sobre a regulamentação do atendimento online}

A chegada da internet ao Brasil trouxe consigo a possibilidade de se realizar atendimentos por computador. Muitos psicólogos se interessaram pela prática antes mesmo que o Conselho Federal de Psicologia se posicionasse a respeito dessa atuação. Foram ofertadas diversas formas de psicoterapia online e os atendimentos em geral eram realizados por escrito, tendo em vista que a qualidade de conexão da época era sofrível. Em pouco tempo, as conexões melhoraram significativamente e, cada vez mais, pessoas se interessavam pelo uso do computador e novos clientes se interessavam em buscar ajuda por esse meio. Consequentemente a oferta de atendimentos também crescia.

Essa informação salta aos olhos do Conselho, que resolve, por não ser ainda uma prática estudada, formar uma comissão que avaliaria o que poderia ou não ser feito a esse respeito. Mas haveria mesmo uma abertura para esse tipo de atendimento? Estaria o Conselho disposto a pensar sobre a questão sem recorrer a pressupostos teóricos? Ou tentaria apenas adequar o que já estava acontecendo, tanto em consultórios como em universidades, ao que era compreendido por Psicologia? Haveria alguma abertura por parte da categoria dos psicólogos ao que se apresentava ao humano no mundo contemporâneo? Se, de alguma forma, a população compreende a internet como passível de abertura para narrar suas histórias, qual seria a possibilidade de psicólogos a isso responderem?

O modelo Clássico de atendimento psicológico daria conta de contemplar essa nova demanda que surgia? Tal modelo ampara-se no ensino tradicional da Psicologia, buscando enquadrá-la na prática pelo saber teórico.

Segundo Figueiredo (1995) a Psicologia, historicamente, se mostrava dividida em três partes, a saber: por um lado, almejava converter os conhecimentos teóricos e restritos à academia em procedimentos técnicos utilizáveis. Por outro lado, buscava a aplicabilidade de testes e medidas diagnósticas nas práticas dos psicólogos, a fim de, posteriormente, desenvolver um modo de pôr em prática o apoio e cuidado próprios da Psicologia, acompanhando o contexto médico (de cuidado, tratamento e cura).

Contudo, para Morato $(2015, \mathrm{p} .50)$, 
intensas e da nova cultura prevalecente, foi possível o surgimento de transformações no modo de compreensão do homem e, portanto, de visões psicológicas mais abrangentes. A Psicologia, como ciência e profissão, era convocada a retomar o dilema de antigas questões, visando dar conta da experiência humana nessa situação de transformações sociais intensas. Em face dessas transformações, as terapêuticas, em termos de tratamento e intervenções clínicas, tiveram que sofrer reformulações dado o novo panorama dos distúrbios psicológicos apresentados pelo homem. A pressão social conduzia à prática psicológica que, por sua vez, era conduzida pelas teorias já consagradas.

Como ciência humana, a Psicologia não pode se desprender da pressão social e de mudanças por ela impostas. Assim, a expansão do espaço virtual passou a ser um fator facilitador para uma busca por ajuda independente do que a Psicologia pudesse oferecer, embora ainda muito pouco se entenda dessa prática.

Notadamente a tecnologia permeia cada vez mais a vida cotidiana. Permeia a ponto de não mais se questionar se existe ou não um mediador quando a utilizamos, a ponto de nem “enxergar" o computador como esse mediador. É como se ele já houvesse se tornado parte daquele que escreve e não mais um veículo a ser pensado para ser utilizado. Escrever um email é como lançar-se mão do contato "tão real" com o outro, sem mesmo se questionar a disponibilidade e presença deste outro.

Nessa medida, questiono se o ambiente/meio onde o atendimento ocorre seria muito mais uma questão para o psicólogo do que para aqueles que buscam ajuda por esse canal. De fato, e-mails começaram a surgir espontaneamente a psicólogos em geral, revelando uma possível prontidão emocional de clientes que pensavam poder ser esse um canal possível para encontrar a ajuda que buscavam.

Nessa direção, Donnamaria (2013, p.22), recorrendo a outros autores sobre a questão do olhar do psicólogo a respeito da prática online, diz:

Ludmer (2008) acredita que a necessidade de conhecer pessoalmente o paciente se trata de uma questão geracional, e que 'possivelmente os analistas, dentre de alguns anos, não estarão tão impregnados desse estilo' (p.605).

Continuando, ainda aponta:

Consoante a essa visão, Muriel (2012) alerta para o fato de que:

"Os psicólogos de hoje foram formados a partir de paradigmas criados antes da Internet, mesmo que como indivíduos, pertençam a esse período. Mas os tempos mudam, e como o tempo passa, novas cortes de universitários ingressam nas faculdades de Psicologia, estudantes que, por serem mais jovens, integraram as tecnologias de comunicação em sua vida cotidiana. Por isso, os psicólogos se encontram numa conjuntura entre seus paradigmas e as 
novas exigências do meio. Em consequência, estão obrigados a avaliar as teorias, técnicas e modelos relacionais sobre os quais foi construído o conhecimento. Essa avaliação é o reflexo da posição ética profissional que propõe modificação, construção de explicações e aplicações de acordo com o meio" (p.362).

Assim, ao começar a perspectiva para atendimento online, houve uma tentativa de adaptação daquele universo ao já conhecido, ou seja, da Psicologia tradicional ao meio virtual. De certa forma, ainda hoje existem profissionais que tentam instaurar uma prática próxima a de seu consultório presencial no meio virtual.

Contudo, se o saber psicológico norteia a compreensão do terapeuta sobre o ser humano e não necessariamente apenas sobre sua forma de ação, encaixar uma forma existente a um novo espaço poderia se tornar algo ineficiente. Seria possível então pensar em uma nova modalidade, ou em uma nova forma de atuação? Como os usuários dessa nova forma poderiam compreender o sentido de cuidado assim experienciado? Seria possível construir uma nova modalidade de atendimento que abarcasse o cuidado necessário ao humano ainda que online? Se possível, como conduzi-lo?

Figueiredo (1995) fala que é a partir da experiência da clínica psicológica enquanto prática que se pode constituir uma teoria. Seguindo nessa direção, seria possível compreender qual a possibilidade de atendimento online pela acontescência da ação clínica conduzindo-se pela aprendizagem significativa e encaminhando outros saberes e ações possíveis para abertura a essa modalidade que se apresenta com certa pujança. Afinal, a internet é uma realidade presente que aponta urgência para compreensão da necessidade de por ela demandar cuidado de si e de como responder a esse apelo como psicólogos. Assim, sendo através da prática que se torna possível um olhar cuidadoso e acurado ao humano e de suas solicitações atuais, é a compreensão desse homem que conduz às possibilidades de cuidado no contexto contemporâneo.

Morato (2015, p. 51), falando de aconselhamento psicológico e referindo-se ao caminhar do profissional psicólogo, mostra essa mesma reflexão:

(...) se antes era possível trabalhar interventivamente ao longo do tempo, agora a ele (psicólogo) impunha-se urgência. Refletindo a própria condição do homem moderno voltado para a vivência, restrito ao imediatismo e desamparado, correndo contra o tempo e conduzido pelas situações, recorre à utilização de técnicas importadas de teorias científicas da Psicologia, como substrato aparador da prática. Não "tem" tempo para refletir e elaborar sua experiência, ou a ela recorrer como aprendizagem para engendrar campo teórico próprio. 
Então, percorrendo as transformações de intervenções psicológicas pelas mudanças do mundo moderno, como compreender esse humano e sua forma de recorrer ao meio virtual para se relacionar? Quais questões humanas perpassam a escritura de um e-mail solicitando "ajuda"? A demanda por esse modo de atendimento estaria sendo compreendida como "efetiva" por aquele que escreve? Qual o sentido para o homem atual poder recorrer a outros modos de cuidado psicológico?

Neste momento, faz-se inevitável voltar aos primeiros anos dessa prática e das dificuldades para seu encaminhamento. Falo especificamente do NPPI por compreender ser este um dos espaços pioneiros no Brasil dentro de instituições acadêmicas a se debruçar a essa questão, além de ter sido o "berço" de meus questionamentos. Dadas às solicitações da comunidade à universidade, e na tentativa de orientar-se para uma prática legal, o Núcleo iniciou diálogos com o Conselho Federal de Psicologia.

Retomo Morato (2013, pg.52/53) ao apresentar os primeiros momentos do surgimento do Aconselhamento Psicológico:

\footnotetext{
A partir da prática abrem-se possibilidades para reflexão agora muito além de apenas uma função/serviço de técnico aferidor e/ou avaliador. Inaugurando-se como uma prática técnica ${ }^{10}$ de fronteira ou passagem entre a ação e o pensar o próprio fazer, possibilita repensar a questão paradigmática da própria Psicologia enquanto ciência e enquanto profissão. (grifos da autora)
}

Assim, nessa mesma direção, tendo em vista a eminência de atendimentos diferentes do molde tradicionais e que se mostravam cada vez mais presentes como atuação a partir de diversos psicólogos, o Conselho de Psicologia percebe a necessidade de verificar a validade e segurança dessa prática diversa para a população. Nessa época, por volta dos anos 2000, existia um movimento contrário a tal prática, questionando, principalmente, a questão da falta de presença física do terapeuta. Isso porque a formação profissional tradicional privilegia a teoria e a construção de um saber embasado principalmente na psicanálise europeia; desse modo, a forma e espaço onde tal modalidade de atendimento aconteceria se tornara alvo de muitos questionamentos e mesmo de restrição à atuação por parte de profissionais que não estivessem realizando atendimentos em caráter unicamente cientifico.

Muito foi discutido a respeito da questão da virtualidade, suas implicações e como isso afetaria o contato entre terapeuta e cliente. Não me atenho a tais discussões tendo em vista que na atualidade, esse não parece ser mais um questionamento presente. Com a introdução e

\footnotetext{
${ }^{10}$ Como tekhne.
} 
banalização do uso da tecnologia, tais questões foram se dissipando, embora para o Conselho de Psicologia ainda existam pontos que proíbam a prática. Mas como tais pontos não estão muito claros, permito-me algumas considerações.

Em seminários abertos no ano de 2011, realizados em São Paulo (pelo Conselho Regional de São Paulo) e em Brasília (pelo Conselho Federal de Psicologia), cujo objetivo questionar tal prática, não foi possível encontrar argumentos ou justificativas que impedissem tal prática ou que a liberassem. Entretanto, o questionamento dirigia-se, e ainda se dirige, a apresentar como questão central a delimitação do número de "sessões" a serem realizadas online. Desse modo, mesmo frente ao movimento internacional, para o qual a psicoterapia via internet já é liberada e estudada há mais de 10 anos em países como Estados Unidos e Israel, o Conselho Federal de Psicologia do Brasil insiste na posição de que tal prática precisa ser mais estudada em nossa realidade antes de uma possível liberação dados os "riscos possíveis". Seria efetivamente um cuidado com a população ou uma restrição devido a outros norteadores dos que conduzem os conselhos?

De qualquer forma, a aceitação para novas atuações têm se mostrado sempre um grande obstáculo por parte da classe dos psicólogos. Acompanho algumas reflexões de Figueiredo (2004, p. 97):

\footnotetext{
No que concerne à maioria dos conhecimentos psicológicos, a situação é muito diversa; de uma certa forma, quase todas as Psicologias contemporâneas são efetiva ou potencialmente alternativas à cisão corpomente. Em acréscimo, todas ou quase todas mobilizam processos e geram efeitos que concernem à dimensão ética da existência, reproduzindo velhas formas ou instituindo formas novas de relação com os outros e consigo mesmo, possibilitando assim, eventualmente, novos modos de estar no mundo, novas instalações do humano. Isto significa que o confronto entre as práticas alternativas e as práticas psi oficiais é muito mais direto e iniludível, já que ambas parecem disputar um mesmo terreno. (...) Ora, a resposta mais fácil dos psicólogos a este desafio tem sido a de reivindicar para si, genericamente e sem considerar a própria diversidade teórica da área, um estatuto de cientificidade que excluiria os "alternativos" da competição.
}

Retomando a primeira regulamentação a respeito dos atendimentos psicológicos online ( $\left.\mathrm{n}^{\circ} 003 / 2000\right)$ e relembrando o momento vivido, houve um movimento que tentava normatizar e inibir a prática existente àquela época. Fica marcado na escolha dos termos utilizados a intenção: "São reconhecidos os serviços psicológicos mediados por computador, desde que não psicoterapêuticos, tais como orientação psicológica”. Alguns questionamentos me acompanham desde essa época. Uma orientação psicológica não poderia ser psicoterapêutica? Ainda, o que seria uma orientação para o Conselho? O que difere uma 
orientação de um atendimento psicológico para o próprio Conselho que utiliza essa nomenclatura? Existiria uma razão na escolha deste termo? Afinal, o que estaria sendo compreendido por "terapêutico" para não incluí-lo em orientação psicológica?

Buscando tal informação não encontrei referências oficiais que esclarecessem essas questões. Na realidade, ao buscar na internet o termo "orientação psicológica", a única referência de fonte segura (Conselhos de Psicologia e Universidades) consta em textos das resoluções referentes ao tema. Será que o termo foi cunhado para cumprir um papel e resolver uma necessidade pertinente à época de sua criação?

Relembrando o movimento desse momento, foi com o surgimento de um grupo chamado GT-ATMC (Grupo de Trabalho - Atendimentos mediados pelo computador) que o Conselho Federal de Psicologia se propôs a questionar as práticas vigentes na interface da Psicologia e informática e encontrar caminhos para normatizar a prática. Assim, na tentativa de encontrar uma possibilidade de continuar o trabalho que se iniciava em algumas instituições e coibir a psicoterapia online por parte de psicólogos não vinculados a universidades, encontrou-se o caminho de denominar a prática como orientação. Desse modo, serviços que já vinham acontecendo, como os de orientação profissional e sexual, poderiam continuar a ocorrer nesse meio, e através da orientação psicológica haveria uma porta de entrada para um trabalho psicológico que vinha se construindo, diferente da psicoterapia.

Buscando responder à questão do que seria orientação psicológica, Fortim (2004) aponta o aspecto breve e pontual da orientação, enquanto Nascimento (2000) discute a delimitação do tempo e não formação de vínculo. Seria, então, uma aproximação da psicoterapia breve? Afinal, esse tipo de atendimento não ocorre também de forma breve e focal?

Com a chegada e a popularização da banda larga de internet ao Brasil, segundo o Ibope/Netratings, o número de internautas, que era de 9,8 milhões de pessoas em 2000, passou para 32 milhões em 2005 segundo o IBGE. Tal aumento no número de internautas conduziu ao aumento de solicitação pelo atendimento online, levando o Conselho de Psicologia a decidir rever a resolução anterior. Assim, surge a resolução 12/2005 que explicita ainda mais a única possibilidade de atendimentos em caráter experimental, criando uma comissão para avaliar e fornecer um selo de funcionamento a todo e qualquer profissional que se dispusesse a atender pelo meio virtual mesmo que em formato de orientação.

Por esse expediente expressava-se à época uma preocupação frente ao uso que os psicólogos estariam fazendo desse espaço e uma tentativa de controlar os atendimentos já existentes. Qual seria a razão para tal modificação? De fato, parece haver uma maior 
necessidade do Conselho em normatizar o tipo de atendimento realizado nesse meio. Seria de fato uma preocupação genuína com os serviços já ofertados? Seria uma mudança na direção do Conselho? Ou ainda, seria uma percepção no aumento do interesse tanto de psicólogos quanto de clientes e para que não fugisse ao controle do modelo legalmente compreendido como "correto", instalou-se um modelo de controle?

De qualquer forma, para obter o selo, o psicólogo deveria submeter seu site a uma comissão avaliadora do Conselho que, não encontrando irregularidades, permitiria a colocação da imagem de um selo que atestaria ser o site credenciado e aprovado pelo CFP. Paralelamente, foi desenvolvida uma cartilha contendo as diretrizes necessárias para a construção e aprovação de sites. Nessa cartilha, disponibilizada online, além de solicitado que se esclarecesse ao cliente questões como privacidade, sigilo, interferências técnicas na internet, apontava-se o limite máximo de 10 atendimentos em orientação online. No entanto, não havia qualquer referência a como tal número fora estipulado, nem tampouco ao porquê de tal limite. Mas, pelo Conselho, ficou instituído esse critério como máximo em troca de mensagens ou atendimentos simultâneos.

Outra questão relacionada ao selo de aprovação pelo CFP apresentava-se pela necessidade de sua renovação anual. Para tal, era preciso submeter novamente o site e aguardar a avaliação com o parecer e o link que validava a aprovação. Contudo, na prática, a maioria dos psicólogos dispostos a seguir a normatização constantemente viam seus sites com selos desatualizados devido à dificuldade do Conselho em averiguar tantos pedidos e enviar os links de aprovação. Ademais, muitos profissionais não implicados diretamente a pesquisas desconheciam a necessidade de tal selo. Atualmente, tal cartilha não se encontra mais disponível, embora ainda haja uma menção a ela no molde atual de cadastramento de sites a que me refiro a seguir.

A resolução 005/2012 apresentou algumas mudanças, decorrentes de seminários ocorridos no Brasil para conhecer e discutir esse modo de atendimento emergente. A questão do limite de 10 orientações, imposto anteriormente, foi debatida conduzindo ao máximo de 20 sessões de orientação, além de abrir-se a possibilidade da realização de supervisão online e da permissão para atendimento a clientes presenciais que eventualmente estivessem fora da sua região de origem e precisassem de atendimento virtual. Por sua vez, o selo foi substituído por um cadastro online, que pode ser consultado pela população para saber se um site de serviços psicológicos online atende às normas legais ou não.

Novamente me questiono, qual o sentido da delimitação do número de atendimentos? Por que agora são 20 e não outro valor qualquer? Lembrando dos seminários do CRP e CFP e 
de reuniões posteriores a esses encontros, o principal argumento para a mudança do limite foi apresentado por psicólogos que expressavam como 10 orientações nem sempre permitiam o correto encaminhamento do cliente. Contudo, o sentido dessa limitação nunca foi amplamente discutido, conduzindo a refletir numa possível arbitrariedade para o encaminhamento de tais determinações legais.

Em outras palavras, as modificações pareciam atender e adequar a resolução a práticas em consultórios particulares, uma vez que o tema não era, e ainda não é, discutido no âmbito acadêmico para formação. Na verdade, é comum o estranhamento frente à informação de proibição de terapia online, e muitos profissionais nem mesmo sabem que tal resolução existe. Nessa direção, pesquisando no Google pelo termo "psicoterapia online", surgem 1.030.000 resultados nacionais, ofertando um serviço que teoricamente é proibido pelo Conselho. Importa lembrar que sites, aprovados para fazer parte do cadastro oficial, não podem fazer qualquer menção à psicoterapia online, assim não fazendo parte deste número encontrado na referida busca. Isto porque, quando um site é submetido à aprovação do Conselho, se houver a palavra psicoterapia online é indicado que seja retirado o termo para ocorrer uma possível autorização. Ainda assim, apesar de tal regulamentação, é possível encontrar sites aprovados que ainda mencionam o termo terapia online, descumprindo também outras regras, como a disponibilização de valor e links para sites externos. Tais modificações teriam sido feitas após a aprovação do CFP? Ou a avaliação e autorização baseiam-se em critérios diferentes por quem as executa?

De qualquer forma, alguns questionamentos permanecem quanto à atual regulamentação dado que certos esclarecimentos fundamentais ainda carecem. O que é compreendido por orientação online, já que não há definição oficial para o termo? Será que profissionais que cadastram seus sites compreendem essa denominação, ou apenas orientamse pela limitação da quantidade de sessões? Será que não se utilizam dessa nomenclatura a fim de ter a permissão do Conselho uma vez que a população em geral não parece saber a distinção entre orientação e psicoterapia? Seria este uma caminho para "burlar" as regras existentes por parte dos psicólogos? Embora seja solicitado pelo órgão competente que seja explicado o que é orientação, ela sempre é colocada de forma vaga, marcando apenas o caráter breve e focal, explicitando seu aspecto não terapêutico, mas ainda não restringindo o modo pelo qual o profissional queira conduzir sua ação. Afinal, um encontro por ser breve e focal não poderia ser terapêutico? Como determinar que não seja terapêutico? Será que posso escolher e determinar como quem atendo compreende um atendimento psicológico? Mais 
adiante retomarei como é entendida da orientação pelo cliente, ao apresentar uma breve pesquisa realizada no NPPI.

\subsection{Algumas considerações a respeito da forma de responder do NPPI}

Tendo em vista todo o questionamento das normatizações do atendimento online, acredito ser importante pensar na prática realizada pelo NPPI. A posição ocupada pelo Núcleo, como referência institucional marcante frente a essa modalidade de atendimento, implica também a necessidade de refletir acerca de suas transformações ao longo do tempo bem como foi influenciado e influenciou as regulamentações.

Considerando as mensagens recebidas pelo serviço, é possível perceber uma transformação no tipo de pedido que chegava ao longo dos anos. Falo do lugar daquela que vivenciou todo esse processo.

Assim, as primeiras mensagens, datadas de 1998 e em alguns anos seguintes, traziam em si um pedido de orientação tal qual a colocada pelo Conselho. Apresentavam-se com um caráter informativo, como se a população buscasse experimentar o meio virtual como forma possível para atendimento. A maioria das mensagens fazia alusão à solicitação de atendimento, contando uma história para, em seguida, pedir uma informação/orientação de como ou onde poder ser atendido presencialmente.

Contudo, com o passar dos anos, ocorreu uma mudança de conteúdo nas mensagens, passando a pedir atendimento pelo próprio e-mail. Desse modo, surgiram questionamentos. Seria uma mudança da população que utiliza o serviço? Seria um fator decorrente da forma de orientação que ocorria no NPPI? Faria alguma diferença para aquele que utiliza o serviço o nome que ele recebe? Se elas escreviam para uma instituição que tinha uma clínica de Psicologia com atendimento presencial, por que faziam essas perguntas? Por que não buscar nesse espaço físico tal ajuda? O que levava alguém a escrever, contar uma parte de sua história para um desconhecido e perguntar sobre qual o melhor encaminhamento a ser dado em seu caso? Estariam esperando algo mais? Qual seria a real motivação por trás daquele que escreve?

Sem ter respostas, mas buscando uma aproximação com o saber psicológico, foi iniciado um movimento de tentativa de compreensão dessas mensagens. As respostas buscavam expressar um cuidado, tentando, de alguma forma, apontar para quem escrevia que sua história havia sido ouvida e seu pedido por atenção e encaminhamento estava sendo levado em consideração. Para isso, antes de cada resposta, o grupo discutia a mensagem recebida como que em supervisão e só então a resposta era redigida. Afinal, o cuidado na escolha das palavras para clareza do conteúdo era muito importante. Muitas vezes o grupo se 
sentava e discutia por horas como construir uma resposta efetiva. Ela era redigida a muitas mãos, pensada em suas variáveis: como sendo redação de terapeuta e como seu sentido poderia ser compreendido pelo outro que nos escrevia. Era um processo artesanal, de construção de saber, de descoberta.

Desse modo, a resposta era trabalhada de forma a tentar gerar em quem havia escrito a sensação de compreensão, de ter sido ouvido e acolhido e de seu pedido ter sido validado. Era um modo de poder comunicar que aquele que procurara estivesse sendo visto no lugar de alguém que pode assumir sua vida e buscar uma ajuda efetiva e presencial. E a esse tipo de orientação denominou-se orientação focal ou geral. Tal nome apresentou-se muitos anos depois, quando outras solicitações apareceram e fez-se necessário por parte da equipe compreender e diferenciar o tipo de trabalho que realizava. A partir do aumento de e-mails e do início de discussões no CPF a respeito das possibilidades e limitações desse tipo de atendimento, o NPPI participou ativamente como forma de legitimar seu trabalho, realizando o que foi denominado como orientação psicológica.

Retornando ao modo como era realizada essa prática no NPPI, os e-mails eram respondidos com no máximo 1 ou 2 trocas de mensagens, sempre tentando conduzir o cliente a refletir e buscar atendimento presencial se fosse necessário. Tal modo tinha por finalidade cumprir a proposta do Conselho. Assim, levando em consideração que o atendimento precisava se encerrar em poucas mensagens, foi importante perceber o quanto a forma como era redigido o texto-resposta era possível direcionar ou não o término ou uma abertura a novas trocas. Recorrer a perguntas geralmente conduzia a novo questionamento e normalmente solicitava uma nova resposta, a menos que explicitamente se apresentasse a pergunta servindo como reflexão sem esperar por resposta.

A esse modo de troca, posteriormente, denominou-se orientação geral. Foi assim chamada pela equipe justamente por tratar de todo e qualquer assunto trazido. Esse modo é o principal e mais realizado desde o início do NPPI até os dias de hoje. Destina-se à maioria das situações, visando promover a quem procura o serviço uma melhor compreensão de sua situação. Quando necessário, é sugerido um encaminhamento para o atendimento presencial. Essa orientação dirige-se à população em geral e visa, atualmente, ser encerrada em até 3 trocas. Optar por até 3 mensagens foi uma maneira de contemplar questões práticas do serviço: para poder cuidar de tantas mensagens recebidas, era necessário criar alguma delimitação. Além disso, seguia-se a norma inicial do Conselho que, embora não postulasse um número, apontava o caráter breve e focal desse atendimento. Pela experiência, em 3 mensagens era possível realizar uma escuta e encaminhamento quando necessário. Contudo, 
as 3 trocas nem sempre eram suficientes para alguns clientes, pois continuavam a enviar mensagens. Em tais situações, sempre havia respostas, procurando tornar os e-mails mais diretos e direcionados a um encaminhamento para atendimento presencial.

Vale aqui ressaltar, que todas as mensagens de cunho pessoal recebidas pelo Núcleo são respondidas. Por uma questão de respeito a quem escreve, independente do conteúdo ser verdadeiro ou não, é sempre enviada uma resposta. Entende-se que se alguém de dispõe a usar seu tempo para redigir uma mensagem, seja ela verdadeira ou fantasiosa, merece um retorno que a trate de forma reflexiva. Afinal, não seria possível verificar a veracidade de tudo, além de não ser esse o escopo do serviço. Eventualmente uma ou outra pergunta poderia ser feita a fim de clarear o que está sendo apresentado, caso a mensagem gerasse muito estranhamento.

Atualmente, muitas coisas se modificaram. $\mathrm{O}$ aumento na quantidade de mensagens recebidas com teor psicológico foi parte da mudança, impossibilitando de as mensagens serem lidas e discutidas em grupo. Enquanto em 2000, chegaram 14 mensagens para atendimento, em 2002 esse número já havia subido para 216 e-mails, média essa que foi se mantendo nos anos posteriores, com pedidos de orientação, além dos outras solicitações feitas ao grupo, para entrevistas e busca de referências bibliográficas. Isto fez com que fossem necessárias adaptações na forma de trabalho. No presente momento, é feita uma leitura e uma divisão das mensagens de orientação entre os membros da equipe. Cada psicólogo é redator de uma mensagem e há um revisor que o ajuda a pensar se o conteúdo está adequado ou não, se a resposta parece transmitir ou não aquilo que se propõe. Apenas alguns casos mais complexos são discutidos pelo grupo, que se encontra presencialmente 2 vezes na semana. Além disso, todas as mensagens respondidas são trocadas em um grupo de mensagens virtual da equipe, a fim de que todos os membros possam ler e opinar caso achem necessário. Isso faz com que seja possível outros olhares sobre a mensagem.

Neste trabalho, atenho-me principalmente ao modo de orientação online realizado pelo NPPI, tendo em vista ser a mais utilizada e que suscita os meus questionamentos, apesar de terem sido nomeadas pelo grupo outras duas formas de atendimento. Entretanto, considero-as como variações da orientação devido a suas especificidades. Apresento, agora, as derivações, para, posteriormente retornar à orientação online.

Para apresentar as outras 2 formas de nomenclatura e atendimento realizados pela equipe é necessário olhar para o surgimento de ambas. Elas apareceram por um pedido externo, mas que encontrou eco na equipe, desse encontro resultando sua construção. Em uma entrevista para o jornal Folha de São Paulo ocorrida em 2006, o repórter publicou erroneamente que o NPPI realizava psicoterapia online para pessoas com uso compulsivo em 
internet, o que redundou em enorme procura por parte deste público. Até tal data, os pedidos que chegavam referentes ao tema, eram ou encaminhados para atendimento presencial pela equipe na Clinica da PUC ou tratados como orientação pontual. Mas frente ao grande número de pessoas que procurou com essa queixa específica vindo de todo o país, abriu-se um questionamento. Seria possível ao NPPI atender essa solicitação via internet?

Empenhada em compreender essa procura, a equipe decidiu criar a denominação de orientação para uso compulsivo em internet ou "vício", e dedicou-se a atender pessoas que escreviam solicitando tal atendimento, para isso sendo necessário escrever dizendo perceberse "viciada" e apresentando a situação em que se encontrava. Ou seja, a mensagem inicial precisaria deixar claro como esse "vício" vinha se apresentando na vida dessa pessoa. Caso não ficasse suficientemente esclarecido, era enviada uma mensagem pedindo mais informações. Uma vez acordada a viabilidade da orientação, eram realizados 5 trocas de mensagens ${ }^{11}$. Posteriormente, esse número foi ampliado para 8 trocas dadas as primeiras experiências que assinalaram ser esse o número necessário para a pessoa poder clarear sua necessidade e mobilizar-se para buscar atendimento presencial.

A terceira denominação é a orientação estendida. Referia-se ao atendimento oferecido ao se evidenciar a dificuldade para buscar acompanhamento presencial a pessoas residentes em locais ermos ou em outros países nos quais não dominavam o idioma, ou ainda quando havia alguma restrição de mobilidade (seja física ou psicológica), ou também por uma situação específica que impossibilitasse alguém para buscar atendimento presencial. Nesses casos, era feito um convite, dizendo que o NPPI ofereceria um atendimento um pouco mais extenso $^{12}$, a fim de possibilitar à pessoa a retomar a capacidade de dispor de suas próprias possibilidades. Neste caso, para iniciar o trabalho, estabelecia-se um protocolo, acordando com o cliente a especificidade do serviço, o limite de sessões e o compromisso com a periodicidade de uma troca de e-mails por semana, com tolerância de até duas para enviar seu retorno. Tal prazo foi determinado a fim de manter o funcionamento do serviço, permitindo algum tempo tanto para o cliente como para o psicólogo poderem ler e confeccionar mensagens. Nesse acordo, aparecem esclarecimento sobre a indicação do CFP quanto a modalidades de atendimento virtual, com a diferenciação entre psicoterapia e orientação online e seu tempo de duração. As pontuações solicitadas pelo Conselho no que se refere a orientação, constam na página do serviço (www.pucsp.br/nppi), além de serem enviadas na mensagem inicial, para o cliente.

\footnotetext{
${ }^{11}$ Por troca, compreende-se o conjunto de 1 mensagem enviada do cliente e uma do terapeuta.

${ }^{12}$ Como já dito, atualmente o CFP limita a 20 sessões o atendimento mediado pelo computador.
} 
Sem dúvida, a experiência foi permitindo que fossem se aprimorando os modos de responder às mensagens. Os e-mails começaram a serem divididos e distribuídos dentro das categorias apresentadas. Assim, a sensação de novidade foi se dissipando e muitas vezes o trabalho, que antes era construído a cada mensagem foi deixando de ser uma construção criativa. Como dito por Farah (2004), a amplitude dos desdobramentos da tarefa assumida e pelo pioneirismo do serviço, houve grandes dificuldades operacionais e institucionais, chegando a ameaçar a continuidade do projeto, embora a criatividade da equipe fosse se estruturando, conseguindo dar conta das tarefas. Importante apontar como esse pioneirismo também foi ressaltado por Donnamaria (2013).

Enfim, de qualquer modo não é possível deixar de refletir acerca de tantas mudanças, considerando a necessidade de submissão às normas do Conselho. Ou também seria possível pensar em um enrijecimento da equipe?

De um lado é inegável o quanto a rigidez frente à orientação e às eternas questões sobre o atendimento online e sua permissão ou não por parte do Conselho fizeram com que o NPPI tentasse se manter acatando a ética e se enquadrando ao que era proposto. Por outro lado, questões internas da direção da Clínica da PUCSP, em muitos momentos, ameaçaram o serviço, pela situação da não regularização dessa modalidade de atendimento. O medo de uma suspensão da permissão para o atendimento online foi por muitos anos companheiro dos membros da equipe em relação a sua prática. Assim, a necessidade de "defesa" da prática e o constante questionamento enfrentado como que intimavam a equipe buscar enquadrar-se em seus atendimentos.

Ao mesmo tempo, pressionada por essas situações, o modo de realização da prática em sua forma de serem construídas as respostas, promovia uma visão de "efetividade" a efetividade tida no serviço fazia com que pouco se questionasse a respeito de formas de se inovar no trabalho. Assim, buscando compreender um pouco sobre essa efetividade, foi realizada uma pesquisa com os usuários do serviço a fim de conhecer como se apresentavam a eles as respostas recebidas nas orientações.

Com o passar dos anos, ocorreu outra mudança de conteúdo e as mensagens, que antes buscavam apenas uma orientação, agora passam a pedir atendimento pelo próprio e-mail. Seria uma mudança na população que utiliza o serviço? Ou seria algo decorrente da forma de orientação que ocorria no NPPI? Seriam necessárias inovações? Seriam necessários questionamentos? Seria necessário manter as orientações da mesma forma como foram apresentadas no início de sua proposta? 
Cada e-mail recebido pede uma discussão, uma supervisão, uma aproximação àquilo que lhes era oferecido. Neste meio tempo, o Conselho de Psicologia também resolve regulamentar essa prática percebendo o quanto as pessoas de uma maneira em geral começaram a se aproximar deste canal e que alguns psicólogos resolveram fazer atendimentos pelo computador.

Do ponto de vista prático, a intervenção clínica do NPPI segue algumas diretrizes:

- Qualquer pessoa que desejar pode enviar uma mensagem ao serviço pedindo uma orientação. Nessa primeira mensagem, caso já seja explicito o que essa pessoa deseja, já é formulada uma resposta contendo a orientação psicológica. A esse tipo de atendimento, denominou-se orientação pontual.

- Se não estiver clara qual a demanda, é enviado em retorno um e-mail pedindo que detalhe um pouco mais o que o vem afligindo e falando a respeito dos limites estabelecidos pelo conselho federal.

- Atender por e-mail é se colocar à disposição do outro naquilo que se apresenta. É estar disponível a uma demanda espontânea, que encerasse em si mesma. É clarificar possibilidades. É ser presente à distância.

Nessa direção, Fortim; Cosentino (2007, p. 168) definem algumas outras possibilidades:

\footnotetext{
Assim, as respostas enviadas podem ter como objetivo possibilitar que o indivíduo reflita sobre a situação, ou, se for um caso mais grave, se sensibilize para procurar ajuda presencial. Nesse sentido, o serviço de orientação contribui para transformar a "queixa" em "demanda", tornando o espaço virtual, possivelmente, um espaço terapêutico, ou, pelo menos, parte dele.
}

Começando de forma padrão, as mensagens geralmente são respondidas com um “Olá", seguido ou não pelo nome da pessoa. Optou-se por essa forma justamente por não ser possível precisar em que momento o outro leria a mensagem; assim, saudar com bom dia, boa tarde e boa noite não seria conveniente. O nome da pessoa só é colocado quando ela assina o final da mensagem ou se refere a si mesma pelo nome; mesmo que o e-mail da pessoa seja um nome pessoal, preferimos não assumir como pertinente chamá-la por aquele nome, entendendo que de alguma forma ela pode estar usando um e-mail de alguém, ou ter criado um e-mail exclusivamente para tal finalidade e talvez, então, aquele não seria seu nome, podendo manter-se a possibilidade de não ser descoberta em sua forma, sentindo-se protegida pelo anonimato. 
Comumente abrimos as respostas com um acolhimento inicial. O acolhimento é tido como forma de traduzir compreensão e abrir espaço para que o outro escute o que temos a dizer de forma mais genuína. Ele marca a compreensão de uma dificuldade, de um sentimento, validando para a pessoa sua experiência do modo como foi expressa.

Geralmente, um dos temas abordados é escolhido pelo psicólogo, normalmente aquele em que se percebeu mais ênfase. Quando se deseja clarear o porquê escolhemos um tema, podemos usar a repetição de uma das frases ditas pelo interlocutor como marcador do assunto. Presencialmente isso não seria necessário, uma vez que a interrupção ocorreria no momento da fala, embora também para dar ênfase pudesse ser repetido o que foi falado.

$\mathrm{O}$ cuidado com as palavras também se faz presente, uma vez que o fato de ser a palavra escrita o único canal de comunicação aqui presente, ela adquire um peso maior. Frequentemente usam-se expressões como "parece" "temos a impressão" e outras que mostrem sugestões de falas e não afirmativas. Este tipo de colocação serve para ajudar o paciente a refletir sobre o assunto, sem sentir que está sendo levado a uma conclusão. Abremse possibilidades, sugestões. Contudo, as afirmativas são também usadas, porém em outros momentos: quando se tem a intenção de uma maior atenção a uma colocação feita pelo autor da mensagem.

A linguagem utilizada na resposta também busca ser o mais coloquial possível. Isso minimiza problemas de interpretação por parte do leitor.

O psicólogo também pode tentar fazer um breve resumo daquilo que o paciente fala sobre o tema, pontuando as sensações que teve, nomeando o que ele contou. Às vezes, generalizações são usadas na construção da mensagem, pois ao se tentar falar de forma ampla sobre um tema é como se assim pudéssemos falar de um assunto de forma quase genérica, usando o todo para falar de alguma questão apresentada pela pessoa. Fica a sensação de pertencimento a um grupo para aquele que lê, tentando diminuir assim a sensação de estranheza que se tem frente as suas dúvidas em um determinado assunto.

Novamente o fato de não estar dialogando com a pessoa em tempo real, faz com que seja necessário o uso da generalização como forma de compreensão mais branda. Mas aqui me questiono: por que é necessário diminuir a estranheza e encaixar o outro na normalidade? Existe algo no e-mail que precisa ser mais acolhedor e normativo ou isso seria apenas um caminho adotado pelo grupo? Na forma de compreensão do NPPI, por ser uma orientação, a intenção do e-mail não é encontrar respostas, nem mesmo clarificar tanto as questões, mas sim deixar claro para aquele que escreve que existem ali coisas que precisam ser trabalhadas em um espaço de tempo maior, com atenção e cuidado. 
No tipo de trabalho que realizamos no NPPI, além de utilizarmos o espaço virtual, temos a particularidade do atendimento ser feito de forma escrita. Recebemos um e-mail escrito, refletimos a respeito, redigimos uma resposta. $O$ fato de ser por escrito tem seus benefícios e seus complicadores. Nicolaci-da-Costa (2005, p. 81) diz:

\footnotetext{
A internet é um espaço de vida alternativo, no qual a escrita é o meio privilegiado de comunicação e de experimentação de novas formas de ser. $\mathrm{O}$ sujeito contemporâneo escreve - ou melhor, tecla - para se comunicar, escreve para construir personagens, escreve para informar, escreve para construir relacionamentos, escreve para registrar pensamentos, escreve para dar sentido às suas experiências múltiplas e diversificadas etc.
}

A linguagem escrita pede uma maior reflexão em sua formulação, além de possibilitar leitura e releitura quantas vezes se desejar. Assim, o cuidado na redação é fundamental, na tentativa de minimizar a má compreensão. Através da escrita do outro, muitas coisas são possíveis de serem observadas com um pouco de treino. É possível perceber a forma como trata o problema, como se sente frente a ele, como se coloca, ver "atos falhos". Cada pessoa imprime seu jeito pessoal em sua mensagem. E para poder tocá-la com uma mensagem é preciso que se pense caso a caso.

Outro ponto importante, parece ser o de assumir qualquer mensagem e seu teor como sendo verdadeiro. Posso questionar a verdade, mas mantenho trabalhar o verdadeiro como possibilidade. Afinal, seguindo Fernando Pessoa ele mesmo, "O poeta é um fingidor que finge tão completamente, que finge ser dor a dor que deveras sente".

\subsection{Outra possibilidade de compreensão: Orientação online e Plantão Psicológico}

Ao fazer a analise clinica percebo uma serie de questionamentos pessoais. Alguns coloquei ao longo do texto, outros separei para este momento final.

Ter pensando nesta troca de e-mails ponto a ponto juntamente com toda a vivência que tive no mestrado, fez-me questionar e repensar a forma como vinha fazendo atendimentos online. Por tudo aquilo que vivenciei durante a construção da orientação online, acredito ter me moldado a todos os pontos que apresentei e me percebi várias vezes durante esse trabalho tentando defender a questão do atendimento virtual. Hoje porém, vejo que não é este o lugar que gostaria de estar.

Não mais questiono como antigamente a possibilidade de atuação nesse meio. Questiono a forma como essa atuação ocorre. Teríamos mesmo que ser tão presos a regras e 
normas que fazem com que fiquemos distantes daquele que nos escreve? Haveria alguma possibilidade de abrir novos rumos dentro do que o Conselho de Psicologia permite?

Durante a análise, senti-me próxima ao cliente. Suas questões pessoais, seus dilemas me tocaram. Estive de fato em sua companhia. Lembrei-me de Benjamin (1985, p.213) "Quem escuta uma história esta em companhia do narrador, mesmo quem a lê partilha dessa companhia."

A maioria de minhas indagações ao ler os e-mails buscavam fazer um levantamento de ideias, para tentar compreende-lo em sua história, em suas vivencias. Alguns pontos são propiciados pelo virtual, outros fazem parte da própria narrativa.

Seria então possível construir uma resposta diferente, algo que mesmo ocorrendo em apenas 1 troca, tivesse um efeito terapêutico? Teria de me ater ao termo orientação que cerceia a resposta e faz com que a riqueza e pluralidade do outro se dissipe?

Para isso seria preciso ter outro olhar para as mensagens. Não porque o anterior não fosse bom, mas por acreditar que pode haver outras possibilidades. Sendo assim, abro-me a outros olhares.

Faria diferença para o cliente o nome que nós, psicólogos, damos a esse trabalho? Como o principal interessado se sente frente as respostas ofertadas? Apresento aqui brevemente alguns dados de uma pesquisa realizada nos anos de 2014/2015 com clientes que escreveram ao NPPI.

Para sua realização foi criado um formulário na internet contendo perguntas a respeito de como os clientes atendidos haviam compreendido o atendimento realizado, além de alguns dados demográficos. Ao final de cada resposta de orientação enviada pela equipe, seguia um convite para que o cliente, caso desejasse, desse sua opinião a respeito do serviço que lhe fora ofertado. Não havia qualquer obrigatoriedade, nem mesmo a de responder a todas as questões. Não era exigida nenhuma identificação. Assim, foi surpreendente que 246 pessoas espontaneamente responderam.

Para a pergunta: "Quanto você acredita que a resposta ajudou/fez refletir sobre suas questões", sendo solicitado que fosse atribuída uma nota entre 0 a 5, 94\% assinalou um valor superior a 3 , enquanto que $43 \%$ atribuiu nota 5 . Desse modo, revelava-se que o objetivo que levou a procura, havia sido atingido. Ao se perguntar se utilizariam o serviço novamente, $88 \%$ afirmou que sim.

Como forma de melhor compreensão, apresento a seguir algumas frases escritas espontaneamente ao ser questionado: "O que você achou do serviço?": 
"Muito bom, na leitura do e-mail percebi que a pessoa foi atenciosa e realmente se propôs a me ajudar"

"Gostei do serviço. A primeira vez que li me emocionei. É sempre difícil falar das minhas emoções, e pude perceber que o meu e-mail foi realmente lido"

"Eu realmente gostei muito, tanto pela qualidade do que foi dito, em que vc percebe que quem leu, prestou atenção de fato no que leu, quanto pelo sentimento de apoio que vc tem quando está fragilizado."

"Muito bom, porém senti falta de um acompanhamento do serviço pela web, já que foi sugerido um atendimento pessoal, o que no meu caso se torna difícil já que na minha localidade não há psicólogo, nem serviços afins. Gostaria de dar continuidade as sessões por aqui."

"Achei interessante porém pouco abrangente e demorado."

"Uma experiência nova, que trouxe a reflexão"

Também os participantes foram questionados sobre o porquê optaram pela ajuda psicológica online:

"Foi o meio que estava mais acessível no momento e por ser mais fácil de se expressar do que verbalmente."

"Pela discrição."

"Falta de \$\$\$ pra consulta presencial"

"Por ser a única ferramenta ao qual eu tinha disponível no momento"

Por essa amostra obtida, tanto numérica quanto qualitativa, é possível compreender como, para o cliente, a orientação online tem se apresentado como um canal de atendimento válido, principalmente por poder ter sido ouvido por alguém. Assim, qual o sentido para essa modalidade de atenção psicológica?

Retomo aqui uma reflexão já apresentada por Ruffo \& Evangelista (s/d) ao apontarem ser possível compreender a demanda por atenção psicológica da mesma maneira que a prática presencial.

Quem sofre é uma existência restrita nas suas possibilidades existenciais. A intervenção clínica mediada pelo computador, assim, se aproximaria daquela realizada na clínica presencial no sentido de propiciar aquele que escreve e é escutado a possibilidade de encontrar sentidos para o que experiência, abrindo-lhe a possibilidade de, posteriormente, buscar outras modalidades de cuidado caso sejam necessárias.

O sofrimento psicológico, motivador da procura pelo psicólogo - seja em clínicas psicológicas, seja por e-mail - é tangenciada por um projeto de reestabelecer a familiaridade cotidiana atualmente rompida. São múltiplos os modos possíveis de rompimento com a 
familiaridade de ser-no-mundo. Sendo o ser-aí poder-ser, nada lhe garante tranquilidade, nem constância nem consegue prescindir totalmente esquivar-se de sua condição de indeterminação. O sofrimento "psicológico", entendido por este viés, é a ruptura da malha cotidiana que abala a identidade das coisas, dos outros e de si mesmo, lançando na indeterminação. Cautella Jr. \& Morato (2010) chamam isso de crise. Nesse sentido, a crise é a situação motivadora da procura pelo psicólogo. Ela não é um acontecimento desprovido de sentido. Pelo contrário, é a irrupção da indeterminação ontológica possibilitadora de apropriação da condição de ter-que-ser, podendo ser definida como "todo acontecimento súbito que retira o homem da comodidade das convicções e da entrega ou dos acordos habituais efetuados em seu cotidiano no mundo" (CAUTELLA JR. \& MORATO, 2010, p.208), rompendo o fluxo aparentemente contínuo da cotidianidade. Por isso pode ser interpretada como momento de quebra na ordem cronológica dos acontecimentos cotidianos, trazendo consigo sofrimento.

Segundo CRITELLI (2012, p.26),

\begin{abstract}
Quando inusitados e inesperados, os acontecimentos provocam uma ruptura com o senso comum. Nossos sofrimentos, em geral, começam quando compreendemos as coisas de uma maneira diferente da habitual, diferente daquela que compartilhávamos com os outros e não temos repertório para identificar e sustentar essa nova compreensão. São eventos para os quais não existe uma interpretação prévia (portanto, ainda não tornada comum), para os quais não estávamos preparados.
\end{abstract}

Nesse sentido, a procura pelo atendimento psicológico é um modo possível de reestabelecer a tessitura cotidiana rompida. Para isso, a existência lança mão dos meios que lhe estão disponíveis. E para muita gente atualmente a internet é o meio mais à mão para comunicar-se.

A atenção psicológica ofertada por e-mail pode apresentar o mesmo sentido da presencial: buscar junto a outro a compreensão de significados e sentido de seus modos de existir, "no sentido tanto do que ele está podendo viver quanto das restrições que impedem o desdobrar das suas possibilidades." (CARDINALLI, 2012, p.79) Isto é, busca o desvelamento dos modos como se coloca e se comporta nas situações atuais de sua vida, reconhecendo que elas atualizam o que e como está sendo possível lidar com elas. Desse modo, esta modalidade poderia ser outro modo de plantão psicológico: aquele que sofre estaria considerando que a procura através de e-mail seria uma das poucas, senão a única, possibilidades de buscar atenção psicológica neste momento de sua vida. 
Assim compreendido, o atendimento online poderia expressar o sentido da ação clínica por e-mail como se aproximando da demanda presencial: proporcionar àquele que procura $\mathrm{o}$ psicólogo por esta ferramenta de comunicação, ou seja, [...] compreensão de seu modo de serno-mundo, abrindo-lhe possibilidades para novas formas de existir, e devolver-lhe a capacidade de dispor das possibilidades próprias e mais autênticas. (BARRETO \& MORATO, 2010, p.45). Nessa direção, a atitude do psicólogo nesta modalidade de aconselhamento psicológico é fenomenológica, pois não visa esgotar o saber, mas, sim, permitir que aquilo que se mostra possa se desvelar da maneira que lhe é possível. Assim, todo e-mail recebido poderia ser orientado apenas como fruto do possível encontro do terapeuta com a mensagem que se desvela. Um terapeuta disponível como plantonista, pois “o objetivo da perspectiva analítica existencial não era a cura nem fazer uma adaptação tranquila, mas propiciar ao cliente a auto compreensão e, por ela, uma atitude de responsabilidade e preocupação para com a própria existência.” (BARRETO \& MORATO, 2010, p.45).

Frente a tantas reflexões a respeito do fazer psicológico no meio virtual, escolho finalizar com Benjamin (1985, p. 200): “Aconselhar é menos responder a uma pergunta que fazer uma sugestão para a continuidade de uma história que está sendo narrada". Nem orientação, nem psicoterapia online. Aconselhamento Psicológico? 


\section{Referências Bibliográficas}

BARRETO, C.L.T.B. \& MORATO,H.T.P. A ação clínica e a perspectiva fenomenológica existencial. In Morato, H.T.P.; Barreto, C.L.B.T.; Nunes, A.P. (org.) Aconselhamento psicológico numa perspectiva fenomenológica existencial. Rio de Janeiro: Guanabara e Koogan, 2009.

BENJAMIN, W. O Narrador. Considerações sobre a obra de Nikolai Leskov. In: Magia e técnica, arte e política: ensaios sobre literatura e história da cultura. 7. Ed. São Paulo: Brasiliense, 1994.

BRASIL. IBGE. Pesquisa nacional por amostra de domicílios, 2005 - Síntese de indicadores. IBGE, 2005. Disponível em:

$<$ http://www.ibge.gov.br/home/estatistica/populacao/trabalhoerendimento/pnad2005>. Acesso em: 12 nov. 2015.

BRASIL. Secretaria de Comunicação Social da Presidência da República. Pesquisa brasileira de mídia 2015: hábitos de consumo de mídia. Disponível em: < http://www.secom.gov.br/atuacao/pesquisa/lista-de-pesquisas-quantitativas-e-qualitativas-decontratos-atuais/pesquisa-brasileira-de-midia-pbm-2015.pdf $>$. Acesso em: 13 nov. 2015.

BRASIL: número de internautas mais que dobra desde 2000. 2006. Disponível em: $<$ http://tecnologia.terra.com.br/noticias/0,,OI1202965EI12884,00Brasil+numero+de+internau tas + mais + que + dobra + desde.html $>$. Acesso em: 12 nov. 2015.

CARDINALLI, I. Daseinanalyse e Esquizofrenia. São Paulo: Escuta, 2012.

CAUTELLA JR., W. \& MORATO, H.T.P. Uma prática psicológica inclusiva em hospital psiquiátrico: do cuidado de ser ao resgate de cidadania. In Morato, H.T.P.; Barreto, C.L.B.T.; Nunes, A.P. (org.) Aconselhamento psicológico numa perspectiva fenomenológica existencial. Rio de Janeiro: Guanabara e Koogan, 2009.

CONSELHO FEDERAL DE PSICOLOGIA - Disponível em: <http://site.cfp.org.br/wpcontent/uploads/2012/07/Resoluxo_CFP_nx_011-12.pdf> (Resolução do conselho federal a respeito de serviços mediados pelo computador 2012). Acesso em: 15 set. 2014.

CONSELHO FEDERAL DE PSICOLOGIA - Disponível em: $<$ http://cadastrosite.cfp.org.br/docs/resolucao2005_12.pdf $>$ (Resolução do conselho federal a respeito de serviços mediados pelo computador 2005). Acesso em: 15 set. 2014.

CONSELHO FEDERAL DE PSICOLOGIA - Disponível em: $<$ http://cadastrosite.cfp.org.br/cadastro/?CFID=7e09a4ea-e4c2-

4dd79f247f57de84e32b\&CFTOKEN=0> (Cadastramento de sites em vigor desde 2012). Acesso em: 15 set. 2014.

CONSELHO FEDERAL DE PSICOLOGIA. Seminário: Serviços Psicológicos On-line. Disponível em: http://psionline.cfp.org.br/. Acesso em: 20 de dez. 2015.

CONSELHO REGIONAL DE PSICOLOGIA DE SÃO PAUlO. Psicologia On-Line São Paulo 2011: Discutindo as Dimensões do Atendimento Psicológico a Distância. Disponível em: 
http://www.crpsp.org.br/portal/comunicacao/webtv_2011_10_06_1/webtv_2011_10_06_1.ht ml. Acesso em: 20 de dez.2015.

COSENTINO, L.A.M. Aspectos evolutivos da interação homem máquina: tecnologia, computador e evolução humana in PRADO, O.Z., FORTIM, I., COSENTINO, L. ( orgs.) Psicologia e informática: produções do III psicoinfo e II jornada do NPPI . São Paulo: Conselho Regional de Psicologia de São Paulo, 2006.

CRITELLI, D. M. Analítica do sentido: uma aproximação e interpretação do real de orientação fenomenológica. São Paulo: EDUC: Brasiliense, 1996.

CRITELLI, D.M. História pessoal e sentido de vida: historiobiografia. São Paulo: EDUC/FAPESP, 2012.

DONNAMARIA, C.P. Experiências de atendimento psicológico grupal via Internet: uma perspectiva psicanalítica / Tese de doutorado - Campinas: PUC-Campinas, 2013.

DONNAMARIA, C. P.; TERZIS, A. Algumas notas sobre as relações humanas mediadas por computadores. Mental, Barbacena, v. 10, n. 18, p. 165-178, jun. 2012. Disponível em $<$ http://pepsic.bvsalud.org/scielo.php?script=sci_arttext\&pid=S167944272012000100009\&ln $\mathrm{g}=\mathrm{pt \& nrm}=\mathrm{iso}>$. acesso em 22 dez. 2015.

FARAH, R. NPPI-Núcleo de Pesquisas em Psicologia e informática- Serviço de informática da Clínica Escola Ana Maria Poppovic In: FARAH, R.M. (org) Psicologia e informática: o ser humano diante das novas tecnologias. São Paulo: Oficina do Livro, 2004.

FIGUEIREDO, L. C. Revisitando as Psicologias: da epistemologia à ética nas práticas e discursos psicológicos. São Paulo: EDUC; Petrópolis, Vozes, 1995.

FIGUEIREDO, L. C. Revisitando as Psicologias: da epistemologia à ética nas práticas e discursos psicológicos. São Paulo: EDUC; Petrópolis, Vozes, 2004.

FORTIM, I. Terapia online e orientação psicológica: diferenças. IN FARAH, R.M. (org) Psicologia e informática: o ser humano diante das novas tecnologias. São Paulo: Oficina do Livro, 2004..

FORTIM, I. ; COSENTINO, L.A.M . Serviço de Orientação Via Email: Novas Considerações. Psicologia Ciência e Profissão, 2007,27,(1), Pgs 164-175, 2007.

GOOGLE. Pesquisa de resultados. Disponível em: $<$ https://www.google.com.br/?gws_rd=ssl $\# \mathrm{q}=$ psicoterapia + online\&start $=0>$. Acesso em: 14 jan. 2016.

LEITÃO, C.F. ; NICOLACI-DA-COSTA, A. M. Psicologia clínica e informática: por que essa inusitada aproximação? Psicologia Clínica Pós-Graduação e Pesquisa (PUC/RJ), Rio de Janeiro, p. 189-205, 2001.

LEVY, P. O que é virtual. São Paulo: Editora 34, 1996.

LEVY, P. Cibercultura. São Paulo: Editora 34, 2010. 
MORATO, H. T. P. Atenção psicológica e aprendizagem significativa. In: MORATO, H. T. P.; BARRETO, C. L. T. B.; NUNES, A. P. (Org.). Aconselhamento Psicológico numa perspectiva fenomenológica existencial: uma introdução. Rio de Janeiro: Guanabara Koogan, 2009.

MORATO, H. T.P. Por entre Plantão Psicológico e Ação Cartográfica Clínica pelos "Caminhos de Floresta". 2015. 225 f. Tese (Livre- Docência - Departamento de Psicologia da Aprendizagem, do Desenvolvimento e da Personalidade.) - Instituto de Psicologia da Universidade de São Paulo, 2015.

NICOLACI-DA-COSTA, A.M. Primeiros contornos de uma nova "configuração psíquica". Cad. CEDES, Campinas, v. 25, n. 65, Apr. 2005.

NOVO, L.C. Considerações acerca da informática na atitude humana: O computador e a internet como ferramentas do se humano IN FARAH, R.M. (org) Psicologia e informática: o ser humano diante das novas tecnologias. São Paulo: Oficina do Livro, 2004.

NASCIMENTO, J. Porque fazer orientação através de e-mails e não psicanálise on-line? In: SAYEG, E. (Ong). Psicologia e Informática: Interfaces e desafios. São Paulo: Casa do Psicólogo, 2000.

PRADO, O.Z. Terapia via internet e relação terapêutica, Dissertação (Mestrado). São Paulo: Instituto de Psicologia da Universidade de São Paulo, 2002.

RUFFO, L.; EVAGENLISTA, P.E. Atendimento psicológico fenomenológico existencial online (no prelo).

SCHMIDT, M. L. S. A experiência de psicólogas na comunicação de massa. Tese de Doutorado. Instituto de Psicologia da Universidade de São Paulo, 1990. 